\title{
Optimization of Ultrasound-Assisted Extraction via Sonotrode of Phenolic Compounds from Orange By-Products
}

\author{
María del Carmen Razola-Díaz ${ }^{1}$, Eduardo Jesús Guerra-Hernández ${ }^{1} \oplus$, Celia Rodríguez-Pérez ${ }^{2,3,4} \oplus^{1}$, \\ Ana María Gómez-Caravaca ${ }^{3,5}$, Belén García-Villanova ${ }^{1}$ (D) and Vito Verardo ${ }^{1,3, *(D)}$ \\ 1 Department of Nutrition and Food Science, Campus of Cartuja, University of Granada, 18011 Granada, Spain; \\ carmenrazola@correo.ugr.es (M.d.C.R.-D.); ejguerra@ugr.es (E.J.G.-H.); belenv@ugr.es (B.G.-V.) \\ 2 Department of Nutrition and Food Science, University of Granada, C/ Santander, 52005 Melilla, Spain; \\ celiarp@ugr.es \\ 3 Biomedical Research Centre, Institute of Nutrition and Food Technology 'José Mataix', University of Granada, \\ Avda del Conocimiento sn, 18100 Granada, Spain; anagomez@ugr.es \\ 4 Instituto de Investigación Biosanitaria ibs.GRANADA, 18071 Granada, Spain \\ 5 Department of Analytical Chemistry, University of Granada, Avda Fuentenueva, 18071 Granada, Spain \\ * Correspondence: vitoverardo@ugr.es
}

\section{check for} updates

Citation: Razola-Díaz, M.d.C.; Guerra-Hernández, E.J.;

Rodríguez-Pérez, C.; Gómez-Caravaca, A.M.; García-Villanova, B.; Verardo, V. Optimization of Ultrasound-Assisted Extraction via Sonotrode of Phenolic Compounds from Orange By-Products. Foods 2021, 10, 1120. https://doi.org/10.3390/foods10051120

Academic Editor: Christopher John Smith

Received: 20 April 2021

Accepted: 13 May 2021

Published: 18 May 2021

Publisher's Note: MDPI stays neutral with regard to jurisdictional claims in published maps and institutional affiliations.

Copyright: (c) 2021 by the authors. Licensee MDPI, Basel, Switzerland. This article is an open access article distributed under the terms and conditions of the Creative Commons Attribution (CC BY) license (https:// creativecommons.org/licenses/by/ $4.0 /)$.

\begin{abstract}
Orange peel is the main by-product from orange juice industry. It is a known source of bioactive compounds, mostly phenolic compounds, and it has been widely studied for its healthy activities. Thus, this research focuses on the establishment of ultrasound-assisted extraction of phenolic compounds in orange peel using a sonotrode. For this purpose, a Box-Behnken design of 27 experiments was carried out with four independent factors-ratio ethanol/water $(v / v)$, time ( $\mathrm{min})$, amplitude (\%), and pulse (\%). Quantitative analyses of phenolic compounds were performed and the antioxidant activity was measured by ABTS and DPPH methods. The validity of the experimental design was confirmed by ANOVA and the optimal sonotrode extraction conditions were obtained by response surface methodology (RSM). The extracts obtained in the established conditions were analyzed by High Performance Liquid Chromatography (HPLC) coupled to mass spectrometer detector and 74 polar compounds were identified. The highest phenolic content and antioxidant activity were obtained using 45/55 ethanol/water $(v / v), 35 \mathrm{~min}$, amplitude $90 \%(110 \mathrm{~W})$, and pulse $100 \%$. The established method allows an increment of phenolics recovery up to $60 \%$ higher than a conventional extraction. Moreover, the effect of drying on phenolic content was also evaluated.
\end{abstract}

Keywords: Box-Behnken design; phenolic compounds; antioxidant activity; orange peel; sonotrode ultrasound-assisted extraction; HPLC-MS

\section{Introduction}

Orange is the second most produced fruit in the European Union, mainly in the countries of the Mediterranean basin where it supposes 6 million tons, almost $10 \%$ of the world production. Increasingly, citrus juices have gained great popularity, representing more than $50 \%$ of the juices available in international trade. From them, orange juice is the main product processed by the beverage industry and consumed throughout the world due to its high nutritional value and desirable sensory characteristics. Orange fruit processing to obtain juices or citrus-based beverages generates large amounts of waste by-products, such as peels, which are a rich source of soluble sugars, phenolic compounds, flavonoids, dietary fibers (cellulose, hemicelluloses, and pectin), vitamins, enzymes, and essential oils [1-5], which can be used for the production of nutritional dietary supplements [6]. Recently, several authors successfully used the orange by-products as ingredients with rheological and functional properties for the formulation of biscuits [7] and jams [8], and as fat replacer [9]. The orange peels have been reported to have antioxidant [10], anti-inflammatory [11], anti-cancer [12], anti-rheumatic [13], anti-diabetic [14], and cardioprotective activities [15], 
mainly attributed to its content in phenolic compounds. However, orange by-product, due to its high moisture content, is easily spoiled. By this way, the drying step is essential for decreasing the moisture content up to a level that inactivate the oxidant, enzymatic, and microbial degradation, ensuring a longer preservation among the time. It also could let to reduce the transport costs in an industrial level. Several drying techniques have been applied to the dehydration of citrus by-products, such as sun drying, hot air drying, freezing drying, microwave drying, etc. Between them, the best one referred to costs and yields and that can be scaled has been demonstrated to be oven-controlled drying [16]. After them, traditionally methods based on maceration and thermal extraction with different solvents such as hexane, acetone, methanol, etc., have been used to recover nutritionally valuable compounds from this type of fruit wastes [17]. According to this approach, the aim of this work is to establish the best ultrasound-assisted extraction via sonotrode to recover the phenolic compounds from orange by-products using food-grade solvents. The antioxidant activity of the extracts was also evaluated by DPPH (2,2-difenil-1-picrylhydrazyl) and ABTS (2,2'-Azino-bis (3-ethylbenzothiazoline-6-sulfonic acid) diammonium salt) assays. Moreover, the effect of drying on the phenolic composition was also evaluated.

\section{Materials and Methods}

\subsection{Chemicals and Samples}

Gallic acid, DPPH and ABTS were purchased from Sigma-Aldrich (St. Louis, MO, USA). $\mathrm{Na}_{2} \mathrm{CO}_{3}$ was purchased from BDH AnalaR (Poole, England). Water was purified using a Milli-Q system (Millipore, Bedford, MA, USA). Vanillic acid, chlorogenic acid, ferulic acid, quercetin, and rutin were also acquired from Sigma-Aldrich (St. Louis, MO, USA). HPLC-grade water, Folin-Ciocalteu reagent and other reagents were purchased from Merck KGaA (Darmstadt, Germany).

Orange by-products (var. Navelina) were obtained after juice production. The resulting by-product was composed by the albedo, flavedo and rests of pulp of the orange with a humidity of $70 \pm 1.5 \%$. For the model the samples were dried at $60{ }^{\circ} \mathrm{C}$ according to Garau et al. [18]. Dried and fresh samples of by-products were grinded and frozen at $-18{ }^{\circ} \mathrm{C}$ until the analyses.

\subsection{Experimental Design}

The conditions for obtaining the highest recovery of phenolic compounds and antioxidant activity from the orange by-products were optimized by using a Box-Behnken design and response surface methodology (RSM). The design was composed by 27 experiments structured in three blocks with three levels $(-1,0,+1)$. Each experiment was carried out in duplicate. The independent variables were ratio ethanol/water $(0: 100,50: 50,100: 0$ $v / v)$, time $(5,25,45 \mathrm{~min})$, amplitude $(20 \%, 60 \%, 100 \%)$, and pulse $(10 \%, 50 \%, 100 \%)$. The dependent variables were adjusted to a second order polynomial model equation (Equation (1)), where $\Upsilon$ represents the response variable, the total phenolic compounds (TPC) or the antioxidant assays ABTS or DPPH, $X_{i}$ and $X_{j}$ are the independent factors that affect the response, and $\beta_{0}, \beta_{\mathrm{i}}, \beta_{\mathrm{ii}}$ and $\beta_{\mathrm{ij}}$ are the regression coefficients of the model (interception, linear, quadratic and interaction terms). Statistica 7.0 package (StatSoft, Tulsa, OK, USA) was used for the mathematical operations and simulations.

Equation (1). Second order polynomial equation.

$$
Y=\beta_{0}+\sum_{i=0}^{4} \beta_{i} X_{i}+\sum_{i=0}^{4} \beta_{i i} X_{i i}^{2}+\sum_{i=0}^{4} \sum_{j=0}^{4} \beta_{i i} X_{i} X_{j}
$$

ANOVA assay was performed in order to evaluate the adjustment of the models having into account the regression coefficients, the $p$-values of the regressions and the lacks of fit. The optimum conditions were established using RSM. 


\subsection{Extraction of Phenolic Compounds from Orange By-Products by Sonotrode Ultrasonic Extraction}

Orange by-products $(0.5 \mathrm{~g})$ were extracted with an ethanol/water solution $(v / v)$ $(100 \mathrm{~mL})$ by a sonotrode (UP400St ultrasonic processor, Hielscher, Germany) according to the parameters showed in Table 1 . After the extraction, the samples were centrifuged at $3500 \mathrm{rpm}$ for $15 \mathrm{~min}$ and the supernatant was stored at $-18^{\circ} \mathrm{C}$ until the analyses.

Table 1. Box-Behnken design with natural and coded values (parenthesis) of the conditions of extraction and the experimental results obtained for TPC, and antioxidant assays (ABTS and DPPH) expressed with the average and the standard deviation.

\begin{tabular}{|c|c|c|c|c|c|c|c|}
\hline & \multicolumn{4}{|c|}{ Independent Factors } & \multicolumn{3}{|c|}{ Dependent Factors } \\
\hline & $\mathrm{X} 1$ & $\mathrm{X} 2$ & $\mathrm{X} 3$ & $X 4$ & $\begin{array}{c}\text { TPC } \\
\text { (mg GAE/g d.w.) }\end{array}$ & $\begin{array}{c}\text { ABTS } \\
\text { (mg TE/g d.w.) }\end{array}$ & $\begin{array}{c}\text { DPPH } \\
\text { (mg TE/g d.w.) }\end{array}$ \\
\hline 1 & $0(-1)$ & $5(-1)$ & $60(0)$ & $50(0)$ & $20.46 \pm 0.18^{\mathrm{e}-\mathrm{g}}$ & $26.67 \pm 0.39 \mathrm{e}, \mathrm{f}$ & $10.55 \pm 0.03^{b}$ \\
\hline 2 & $100(1)$ & $5(-1)$ & $60(0)$ & $50(0)$ & $10.33 \pm 0.10^{b}$ & $11.56 \pm 0.26^{\mathrm{a}}$ & $10.94 \pm 0.21^{\mathrm{c}}$ \\
\hline 3 & $0(-1)$ & $45(1)$ & $60(0)$ & $50(0)$ & $21.64 \pm 0.21^{\mathrm{f}-\mathrm{i}}$ & $24.92 \pm 0.06^{\mathrm{d}, \mathrm{e}}$ & $19.79 \pm 0.04^{\mathrm{i}}$ \\
\hline 4 & $100(1)$ & $45(1)$ & $60(0)$ & $50(0)$ & $19.55 \pm 0.35^{\mathrm{e}}$ & $18.28 \pm 0.38^{b}$ & $11.07 \pm 0.06^{\mathrm{c}}$ \\
\hline 5 & $50(0)$ & $25(0)$ & $20(-1)$ & $10(-1)$ & $25.33 \pm 0.14^{1}$ & $25.21 \pm 0.26^{\mathrm{d}, \mathrm{e}}$ & $20.02 \pm 0.06^{i}$ \\
\hline 6 & $50(0)$ & $25(0)$ & $100(1)$ & $10(-1)$ & $21.95 \pm 0.16^{g-j}$ & $36.62 \pm 0.50^{n-p}$ & $18.54 \pm 0.05^{\mathrm{f}}$ \\
\hline 7 & $50(0)$ & $25(0)$ & $20(-1)$ & $100(1)$ & $25.12 \pm 0.35^{1}$ & $39.13 \pm 0.79^{\mathrm{o}-\mathrm{q}}$ & $21.05 \pm 0.04^{\mathrm{k}, 1}$ \\
\hline 8 & $50(0)$ & $25(0)$ & $100(1)$ & $100(1)$ & $29.75 \pm 0.36^{\mathrm{m}}$ & $30.14 \pm 0.01^{h, i}$ & $20.95 \pm 0.05^{\mathrm{k}}$ \\
\hline 9 & $50(0)$ & $25(0)$ & $60(0)$ & $50(0)$ & $23.59 \pm 0.92^{\mathrm{j}, \mathrm{k}}$ & $34.97 \pm 0.13^{1, m}$ & $22.43 \pm 0.06^{\mathrm{m}, \mathrm{n}}$ \\
\hline 10 & $0(-1)$ & $25(0)$ & $60(0)$ & $10(-1)$ & $20.08 \pm 0.35^{\mathrm{e}, \mathrm{f}}$ & $36.27 \pm 0.26^{1-n}$ & $21.21 \pm 0.05^{\mathrm{k}, 1}$ \\
\hline 11 & $100(1)$ & $25(0)$ & $60(0)$ & $10(-1)$ & $10.11 \pm 0.37^{\mathrm{b}}$ & $22.87 \pm 0.51^{\mathrm{c}}$ & $11.16 \pm 0.04^{c}$ \\
\hline 12 & $0(-1)$ & $25(0)$ & $60(0)$ & $100(1)$ & $21.95 \pm 0.42^{\mathrm{h}-\mathrm{k}}$ & $33.07 \pm 0.78^{\mathrm{j}, \mathrm{k}}$ & $19.93 \pm 0.05^{\mathrm{i}}$ \\
\hline 13 & $100(1)$ & $25(0)$ & $60(0)$ & $100(1)$ & $16.27 \pm 0.35^{\mathrm{c}, \mathrm{d}}$ & $23.60 \pm 0.77^{c, d}$ & $15.44 \pm 0.05^{\mathrm{e}}$ \\
\hline 14 & $50(0)$ & $5(-1)$ & $20(-1)$ & $50(0)$ & $21.30 \pm 0.03^{\mathrm{f}-\mathrm{h}}$ & $37.18 \pm 0.77^{\mathrm{m}-\mathrm{o}}$ & $19.03 \pm 0.05^{g}$ \\
\hline 15 & $50(0)$ & $45(1)$ & $20(-1)$ & $50(0)$ & $22.40 \pm 0.14^{\mathrm{h}-\mathrm{k}}$ & $36.28 \pm 0.64^{m-p}$ & $23.07 \pm 0.05 \mathrm{p}$ \\
\hline 16 & $50(0)$ & $5(-1)$ & $100(1)$ & $50(0)$ & $10.31 \pm 0.04^{\mathrm{b}}$ & $29.71 \pm 0.27 \mathrm{~g}, \mathrm{~h}$ & $22.69 \pm 0.06^{\circ}$ \\
\hline 17 & $50(0)$ & $45(1)$ & $100(1)$ & $50(0)$ & $23.03 \pm 0.14^{\mathrm{j}, \mathrm{k}}$ & $40.92 \pm 0.64 \mathrm{q}$ & $22.23 \pm 0.05^{\mathrm{m}}$ \\
\hline 18 & $50(0)$ & $25(0)$ & $60(0)$ & $50(0)$ & $22.35 \pm 0.07^{\mathrm{h}-\mathrm{k}}$ & $34.92 \pm 0.59^{\mathrm{k}, 1}$ & $21.20 \pm 0.08^{1}$ \\
\hline 19 & $0(-1)$ & $25(0)$ & $20(-1)$ & $50(0)$ & $20.56 \pm 0.35^{\mathrm{e}-\mathrm{g}}$ & $32.53 \pm 0.37^{\mathrm{j}, \mathrm{k}}$ & $23.19 \pm 0.06^{p}$ \\
\hline 20 & $100(1)$ & $25(0)$ & $20(-1)$ & $50(0)$ & $8.66 \pm 0.06^{\mathrm{a}}$ & $26.33 \pm 0.12^{e, f}$ & $9.54 \pm 0.04^{\mathrm{a}}$ \\
\hline 21 & $0(-1)$ & $25(0)$ & $100(1)$ & $50(0)$ & $22.81 \pm 0.26^{\mathrm{j}, \mathrm{k}}$ & $32.51 \pm 0.03^{\mathrm{j}, \mathrm{k}}$ & $20.29 \pm 0.05^{j}$ \\
\hline 22 & $100(1)$ & $25(0)$ & $100(1)$ & $50(0)$ & $15.98 \pm 0.21^{\mathrm{c}}$ & $27.35 \pm 0.96^{\mathrm{f}, \mathrm{g}}$ & $12.30 \pm 0.04^{\mathrm{d}}$ \\
\hline 23 & $50(0)$ & $5(-1)$ & $60(0)$ & $10(-1)$ & $17.30 \pm 0.42^{\mathrm{d}}$ & $35.04 \pm 0.19^{1-n}$ & $19.41 \pm 0.04^{h}$ \\
\hline 24 & $50(0)$ & $45(1)$ & $60(0)$ & $10(-1)$ & $20.42 \pm 0.09 \mathrm{e}^{\mathrm{e}-\mathrm{g}}$ & $38.15 \pm 0.76^{\mathrm{p}, \mathrm{q}}$ & $21.28 \pm 0.04^{1}$ \\
\hline 25 & $50(0)$ & $5(-1)$ & $60(0)$ & $100(1)$ & $23.37 \pm 0.13^{\mathrm{k}}$ & $28.93 \pm 0.15^{\mathrm{g}, \mathrm{h}}$ & $26.45 \pm 0.04^{\mathrm{r}}$ \\
\hline 26 & $50(0)$ & $45(1)$ & $60(0)$ & $100(1)$ & $25.30 \pm 0.08^{1}$ & $31.37 \pm 0.37^{i, j}$ & $25.65 \pm 0.04 \mathrm{q}$ \\
\hline 27 & $50(0)$ & $25(0)$ & $60(0)$ & $50(0)$ & $22.52 \pm 0.36^{\mathrm{i}-\mathrm{k}}$ & $32.62 \pm 0.27^{\mathrm{j}, \mathrm{k}}$ & $22.61 \pm 0.01^{\mathrm{n}, \mathrm{o}}$ \\
\hline
\end{tabular}

$\mathrm{X}_{1-4}$ : Ethanol/water $(v / v)$, time ( $\left.\mathrm{min}\right)$, amplitude (\%), pulse (\%). TPC: Total phenolic compounds. GAE: Gallic acid equivalents. TE: Trolox equivalents. d.w.: dry weight. Different letters in the same column showed significant differences.

\subsection{Conventional Extraction of Phenolic Compounds from Orange By-Products}

The conventional extraction was carried out according to Abdurrahman et al. [19] with slightly modifications. Briefly, $0.5 \mathrm{~g}$ of orange by-products was added of $100 \mathrm{~mL}$ of ethanol/water $(45 / 55 \mathrm{v} / \mathrm{v})$ and it was agitated by a magnetic stirrer during $35 \mathrm{~min}$ at $35^{\circ} \mathrm{C}$. The samples were centrifuged at $3500 \mathrm{rpm}$ for $15 \mathrm{~min}$ and the supernatant were collected and stored at $-18{ }^{\circ} \mathrm{C}$ until the analyses.

\subsection{Determination of Total Phenolic Compounds by Folin-Ciocalteu Assay}

Total phenolic compounds were determined by Folin-Ciocalteu spectrophotometric method [20]. Thus, $100 \mu \mathrm{L}$ of the extract was added of $500 \mu \mathrm{L}$ of Folin-Ciocalteu reagent and $6 \mathrm{~mL}$ of MilliQ water. The flask was agitated for a minute. After that, $2 \mathrm{~mL}$ of $15 \%$ $(w / v) \mathrm{Na}_{2} \mathrm{CO}_{3}$ was added and made up to $10 \mathrm{~mL}$ with MilliQ water, and stored at dark 
conditions. The measures were carried out after $2 \mathrm{~h}$ at $750 \mathrm{~nm}$ and $25{ }^{\circ} \mathrm{C}$ with a UVVisible spectrophotometer (Spectrophotometer 300 Array, UV-Vis, single beam, Shimadzu, Duisburg, Germany). The results were compared to a standard curve of gallic acid (1, 5, $10,25,50,100,250 \mathrm{ppm}$ ) to calculate the TPC. Results are expressed as mg gallic acid equivalents (GAE)/g dry weight (d.w.).

\subsection{Determination of Phenolic Compounds from Orange By-Products by HPLC-ESI-TOF-MS}

The analyses of the orange by-products using the optimized conditions obtained with the Box-Behnken design were carried out in duplicate on an ACQUITY Ultra Performance LC system (Waters Corporation, Milford, MA, USA) coupled to an electrospray ionization (ESI) source operating in the negative mode and a time-of-flight (TOF) mass detector (Waters Corporation, Milford, MA, USA). The compounds of interest were separated on an ACQUITY UPLC BEH Shield RP18 column $(1.7 \mu \mathrm{m}, 2.1 \mathrm{~mm} \times 100 \mathrm{~mm}$; Waters Corporation, Milford, MA, USA) at $40{ }^{\circ} \mathrm{C}$ using a gradient previously stated by Verni et al. [21] using water containing $1 \%$ acetic acid as mobile phase $\mathrm{A}$ and acetonitrile as mobile phase $\mathrm{B}$. The data were elaborated using MassLynx 4.1 software (Waters Corporation, Milford, MA, USA).

\subsection{Antioxidant Assays DPPH and ABTS}

The antioxidant capacity was evaluated in the 27 orange by-products extracts by two different methods. The first one was the developed by Re at al. [22] in which the monocation $\mathrm{ABTS}^{\bullet+}$ is generated by oxidation of the ABTS with potassium persulfate in the dark at room temperature for 12-24 h. For each extract, it was added $1 \mathrm{~mL}$ of this ABTS solution to $0.01 \mathrm{~mL}$ of extract and it was measured the detriment of absorbance during $10 \mathrm{~min}$ at $734 \mathrm{~nm}$. The results were compared with a standard curve of Trolox $(1,10,20$, $50,80,100,150,200 \mathrm{ppm})$. DPPH radical scavenging activity was assayed with a method proposed by several authors $[23,24]$. Then, $100 \mu \mathrm{L}$ of each extract was added of $2.9 \mathrm{~mL}$ of $\mathrm{DPPH}$, and after rapid stirring, the bleaching power of the extract was observed in a time interval from 0 to $30 \mathrm{~min}$ at $517 \mathrm{~nm}$. The results were compared with a standard curve of Trolox in methanol/water $(4: 1, v / v)(1,10,20,50,80,100,150,200 \mathrm{ppm})$. Results for both assays are expressed as mg Trolox equivalents (TE)/g d.w.

\section{Results and Discussion}

\subsection{Determination of Total Phenolic Compounds and Antioxidant Capacity in Orange By-Products}

The Box-Behnken model coupled to response surface methodology was used to optimize the extraction of the extract with the highest TPC and the highest antioxidant capacity (Table 1$)$.

For TPC, the observed values ranged between 8.7 and $29.7 \mathrm{mg} \mathrm{GAE} / \mathrm{g}$ d.w. The lowest value corresponds to the conditions 100\% ethanol, $25 \mathrm{~min}, 20 \%$ amplitude, and 50\% pulse, and the highest one to ethanol/water (50:50,v/v), $25 \mathrm{~min}, 100 \%$ amplitude, and $100 \%$ pulse.

For the antioxidant assays, values ranged from 9.5 to $26.4 \mathrm{mg} \mathrm{TE} / \mathrm{g} \mathrm{d} . \mathrm{w}$. with the DPPH technique, and from 11.5-40.5 mg TE/g d.w. with the ABTS one. The minimum value with both methods was obtained using only ethanol $(100 \%)$, whereas the highest ones were observed by using a mixture of 50\% ethanol and 50\% water, similarly to the results described for TPC.

\subsection{Fitting the Model}

The experimental data was analyzed adjusting it to a second order polynomial equation, a regression model that, using the least squares method, provides the lowest residual value (Equation (1)). All the regression coefficients are shown in Table 2. 
Table 2. Estimated regression coefficients of the adjusted second-order polynomial equation and analysis of variance (ANOVA) of the model.

\begin{tabular}{|c|c|c|c|c|c|c|}
\hline \multirow{3}{*}{$\begin{array}{l}\text { Regression } \\
\text { Coefficients }\end{array}$} & \multicolumn{6}{|c|}{ Response } \\
\hline & \multicolumn{2}{|c|}{ TPC } & \multicolumn{2}{|c|}{ ABTS } & \multicolumn{2}{|c|}{ DPPH } \\
\hline & Effect & $p$ Value & Effect & $p$ Value & Effect & $p$ Value \\
\hline$\beta_{0}$ & $20.9165 *$ & 0.0000 & $25.5081 *$ & 0.0000 & 16.4511 * & 0.0001 \\
\hline \multicolumn{7}{|l|}{ Lineal } \\
\hline$\beta_{1}$ & $-7.39159 *$ & 0.0000 & $-6.9354 *$ & 0.000 & $-7.1540 *$ & 0.0036 \\
\hline$\beta_{2}$ & $7.14405^{*}$ & 0.0001 & $4.1242 *$ & 0.0189 & 3.9375 * & 0.0343 \\
\hline$\beta_{3}$ & 0.1177 & 0.8784 & -2.5229 & 0.6391 & 1.2579 & 0.7225 \\
\hline$\beta_{4}$ & $5.0592 *$ & 0.0002 & $-6.3625^{*}$ & 0.0227 & $4.2319 *$ & 0.0215 \\
\hline \multicolumn{7}{|l|}{ Crossed } \\
\hline$\beta_{12}$ & 4.0196 * & 0.0211 & 4.2385 & 0.1091 & $-4.5509 *$ & 0.0274 \\
\hline$\beta_{13}$ & 2.5322 & 0.0637 & 0.5152 & 0.7383 & 2.8321 & 0.0665 \\
\hline$\beta_{14}$ & 2.1488 & 0.0855 & 1.9652 & 0.2811 & 2.7874 & 0.0684 \\
\hline$\beta_{23}$ & $5.8083 *$ & 0.0023 & 6.0598 * & 0.0182 & -2.2457 & 0.4190 \\
\hline$\beta_{24}$ & -0.5977 & 0.4677 & -0.3305 & 0.8286 & -1.3348 & 0.2248 \\
\hline$\beta_{34}$ & 4.0099 * & 0.0214 & $-10.1977 *$ & 0.0005 & 0.6917 & 0.4634 \\
\hline \multicolumn{7}{|l|}{ Quadratic } \\
\hline$\beta_{11}$ & $1.9745^{*}$ & 0.0001 & 12.6447 * & 0.0000 & 8.0299 * & 0.0020 \\
\hline$\beta_{22}$ & -1.0824 & 0.1228 & $7.1362 *$ & 0.0000 & $2.1692 *$ & 0.03400 \\
\hline$\beta_{33}$ & -1.6717 & 0.0569 & 0.7439 & 0.4660 & 1.1751 & 0.1326 \\
\hline$\beta_{44}$ & $-2.2687^{*}$ & 0.0336 & 1.9455 & 0.1091 & 0.4520 & 0.3771 \\
\hline $\mathrm{R}^{2}$ & \multicolumn{2}{|c|}{0.9564} & \multicolumn{2}{|c|}{0.9286} & \multicolumn{2}{|c|}{0.8694} \\
\hline$p$ Model & \multicolumn{2}{|c|}{0.0011} & \multicolumn{2}{|c|}{0.0043} & \multicolumn{2}{|c|}{0.0001} \\
\hline$p$ Lack of fit & \multicolumn{2}{|c|}{0.1522} & \multicolumn{2}{|c|}{0.2624} & \multicolumn{2}{|c|}{0.1117} \\
\hline
\end{tabular}

* Significant at $\alpha \leq 0.05 ; 1$ Ethanol/water ratio $(v / v), 2$ time, 3 amplitude, 4 pulse.

The non-significant terms with a significance level of $p<0.05$ were discarded, and the model was recalculated only with significant terms. For the three response variables, the individual linear factors ratio ethanol/water $\left(\beta_{1}\right)$, time $\left(\beta_{2}\right)$ and pulse $\left(\beta_{4}\right)$ showed significant effects. For the TPC and DPPH, the crossed interaction $\beta_{12}$ was significant, and the crossed interactions $\beta_{23}$ and $\beta_{34}$ were significant for TPC and ABTS. Moreover, the quadratic term $\beta_{11}$ was significant for the three response variables; meanwhile, $\beta_{22}$ was significant for ABTS and DPPH, and $\beta_{44}$ only for TPC. The amplitude $\left(\beta_{3}\right)$ and the rest of interactions did not have significant effect in the meanings chosen. In addition, for the three responses it was revealed a high correlation between the factors and the response variable $\left(\mathrm{R}^{2}=0.9564,0.9286\right.$, and 0.8694 for TPC, ABTS and DPPH, respectively). The validity of the model was tested with ANOVA, which showed that, the models can be statistically accepted because the regression model $p$ values are lower than 0.05 and the lacks of fit for the three variables are non-significant $(p>0.05)$.

\subsection{Confirmation of the Optimal Extraction Parameters by Sonotrode}

To establish the optimal conditions of extraction, the obtained response surfaces (Figures 1-3) were studied.

As can be seen in the figures, the major content of phenolic compounds with the highest antioxidant activity could be obtained with the highest amplitude and pulse values and the intermedium ethanol/water ratio and time values.

Briefly, optimal sonotrode extraction conditions were $45 \%$ ethanol/water $(v / v), 35 \mathrm{~min}$, amplitude $90 \%(110 \mathrm{~W})$, and pulse $100 \%$ (Table 3). Verifying the accuracy of the mathematical model, the obtained values did not report significant differences with the predicted values, showing coefficients of variation $<1$ in the case of the total phenolic compounds, and the antioxidant assays (DPPH and ABTS). According to the results, ethanol was not an efficient solvent when used pure, showing better results when it was combined with water in a proportion equal or minor to $50 \%$. This occurs due to the increased solvation 
provided by the presence of water. Additionally, the optimum time was chosen as lower as possible in order to develop a quick procedure. The highest values of amplitude and pulse are necessary in order to reach higher powers and finally obtain better performances.

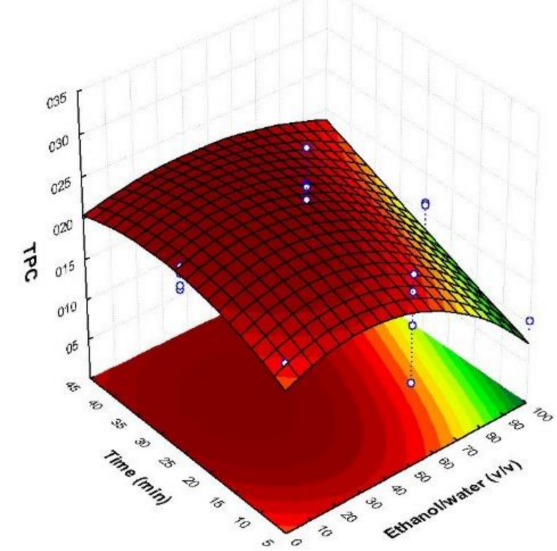

(a)

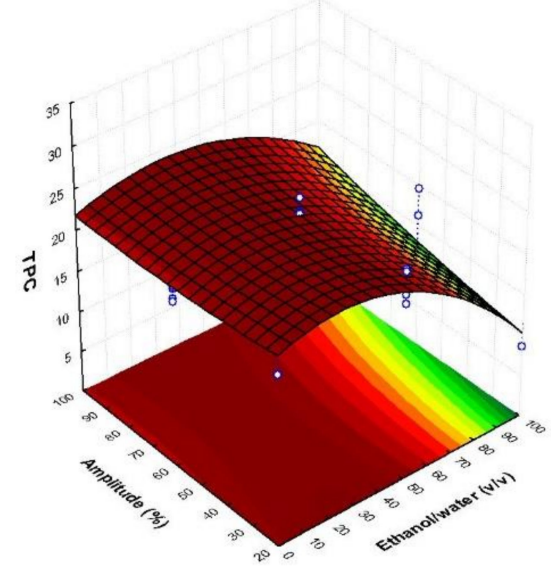

(c)

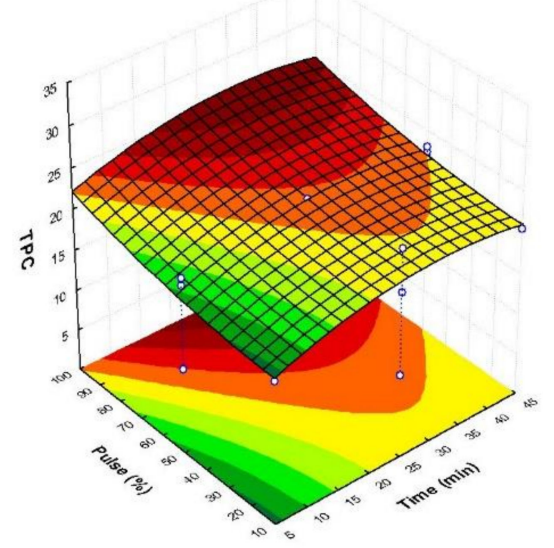

(e)

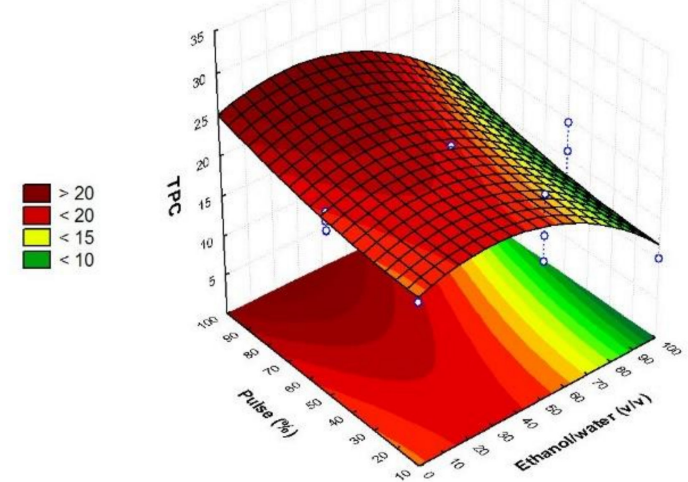

(b)
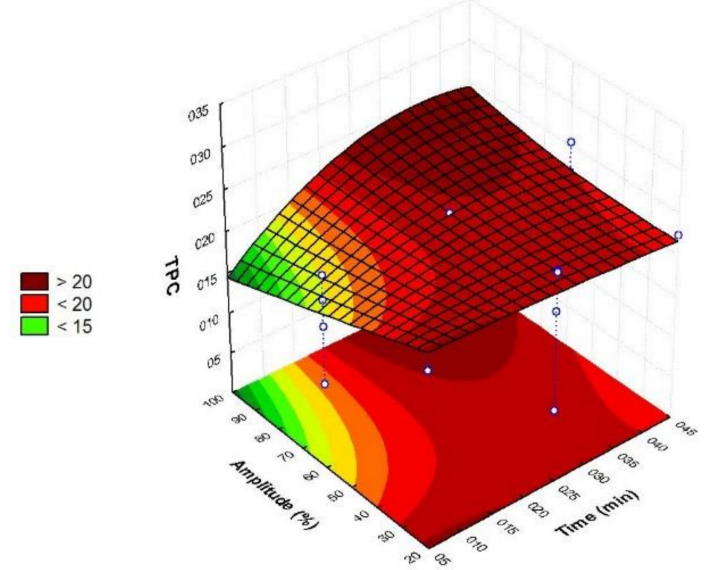

(d)

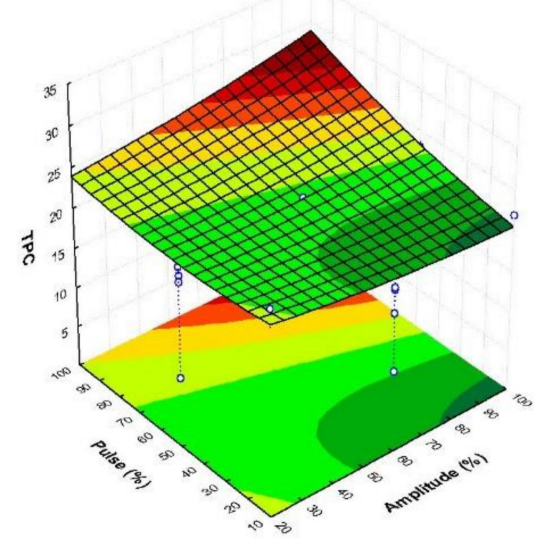

(f)

Figure 1. Response surface graphs (a-f) showing the combined effects of the process variables: Ethanol/water $(v / v)$, time (min), amplitude (\%), and pulse (\%), for TPC (mg GAE/g d.w.). 


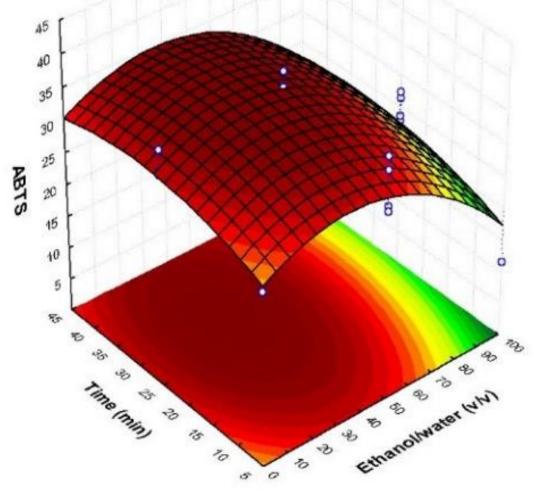

(a)

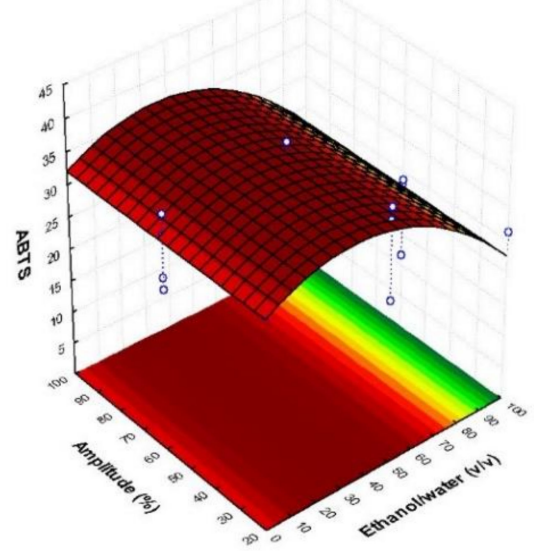

(c)

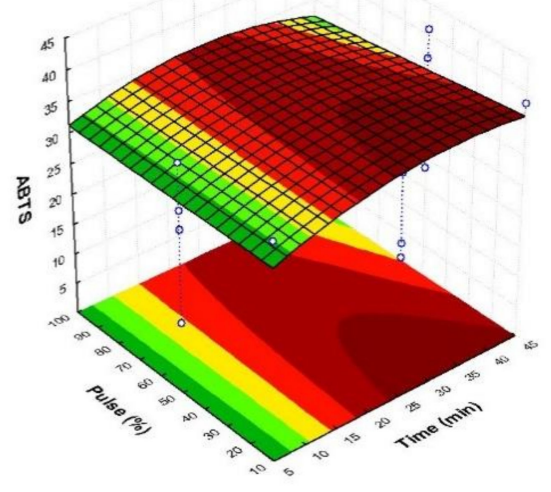

(e)

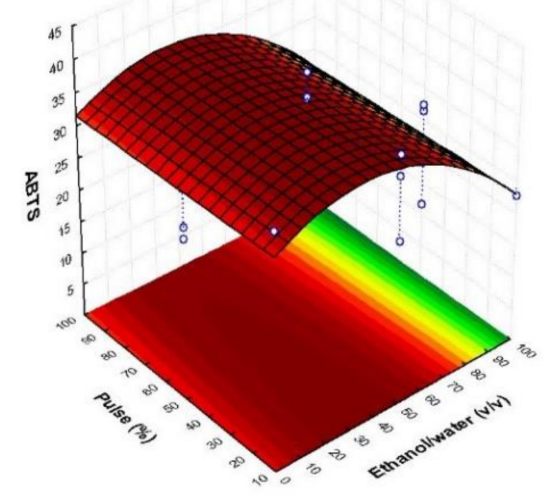

(b)

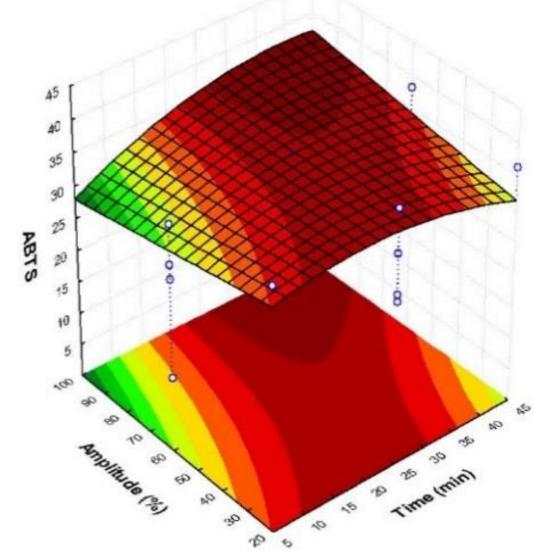

(d)

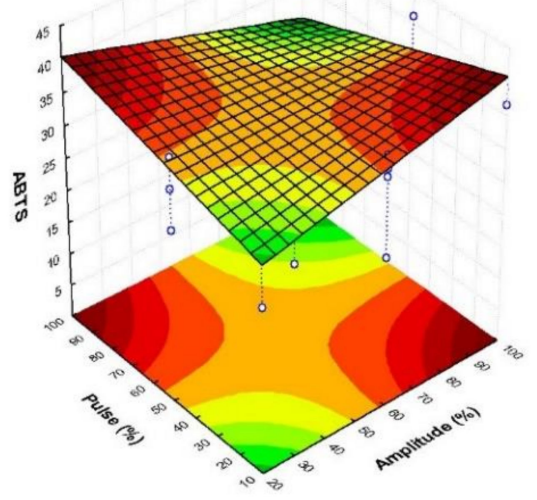

(f)

Figure 2. Response surface graphs (a-f) showing the combined effects of the process variables: Ethanol/water $(v / v)$, time (min), amplitude (\%), and pulse (\%), for ABTS antioxidant assay (mg TE/g d.w.). 


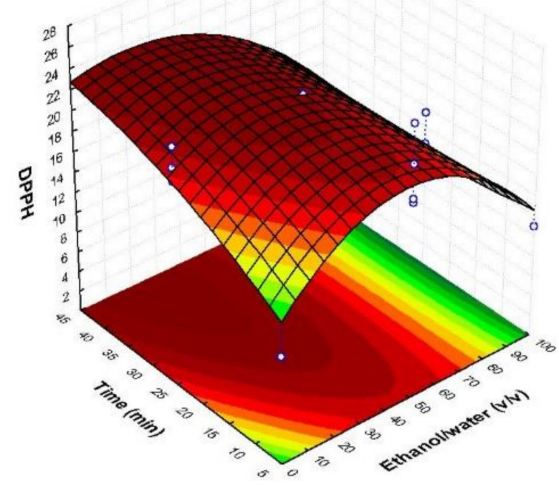

(a)

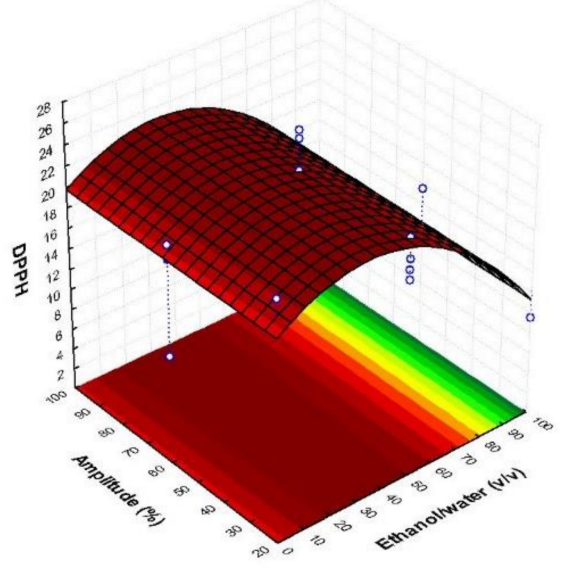

(c)

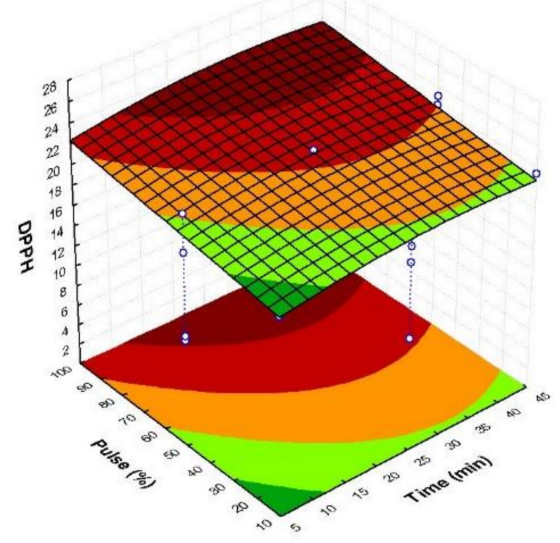

(e)

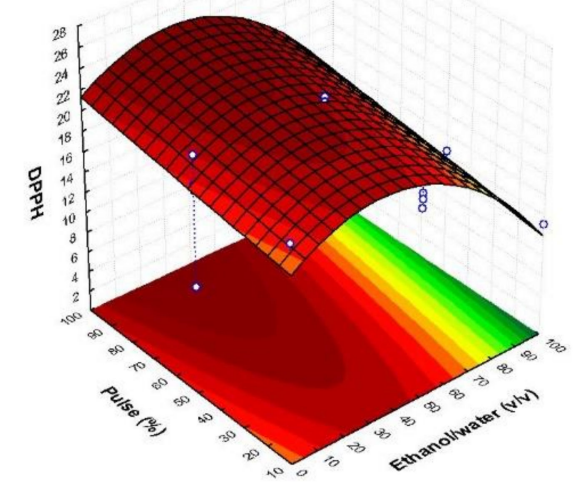

(b)

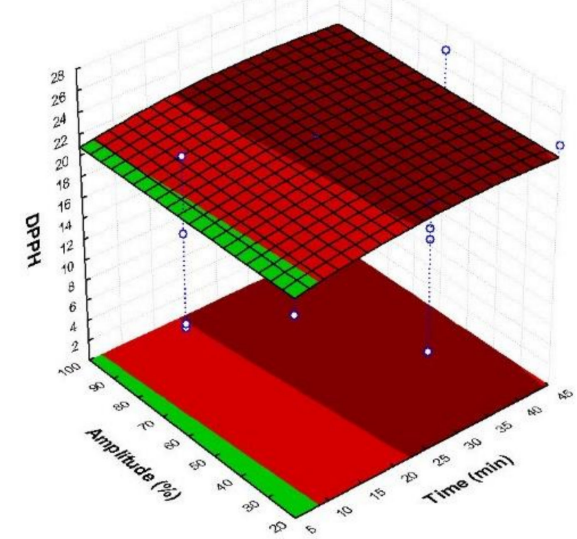

(d)

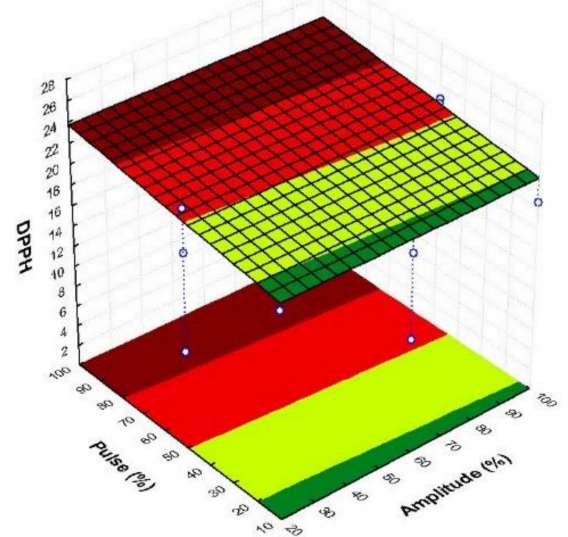

(f)

Figure 3. Response surface graphs (a-f) showing the combined effects of the process variables: Ethanol/water $(v / v)$, time (min), amplitude (\%), and pulse (\%), for DPPH antioxidant assay (mg TE/g d.w.). 
Table 3. Optimal conditions selected and the model predicted values with the obtained values expressed with the mean and the standard deviation.

\begin{tabular}{cccc}
\hline Parameter & \multicolumn{3}{c}{ Optimal Conditions } \\
\hline Ethanol/water $(v / v)$ & & 45 & \\
Time (min) & & 35 & \\
Amplitude (\%) & & 90 & \\
Pulse (\%) & TPC & DPPH & ABTS \\
\hline & $29.36 \pm 3.5$ & $24.44 \pm 3.6$ & $32.02 \pm 7.0$ \\
Predicted value (mg/g d.w.) & $30.42 \pm 1.5$ & $26.37 \pm 1.6$ & $35.62 \pm 2.1$ \\
Obtained value (mg/g d.w.) & 0.025 & 0.053 & 0.075 \\
Coefficient of variation & & &
\end{tabular}

The value of TPC obtained by sonotrode was compared with the same values of the extract obtained by the conventional extraction. The recovery of phenolic compounds by the proposed extraction using sonotrode was $60 \%$ higher than obtained with the conventional one (Figure 4).

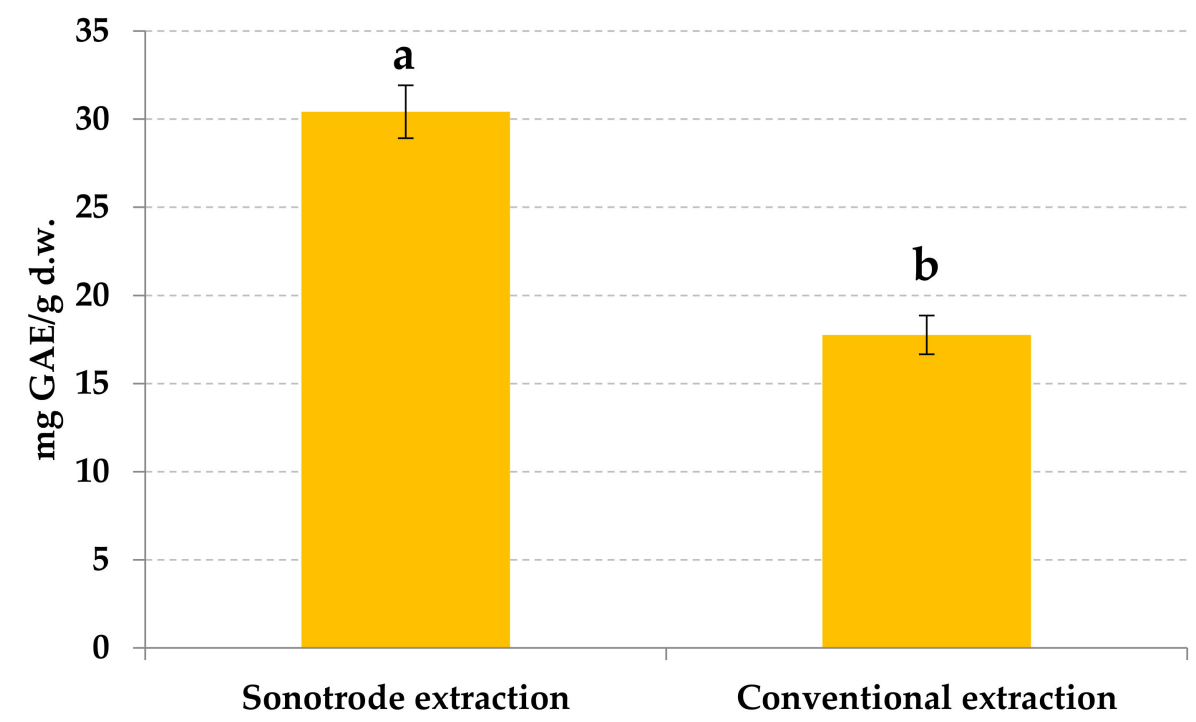

Figure 4. Comparison of phenolic content in orange by-products extracts obtained by sonotrode and conventional extraction. Different letters reported statistical significant differences.

Victor et al. [25] and Lagha-Benamrouche et al. [26] reached similar results than the reported in this study but using higher times of extraction. Other authors optimized the phenolic extraction from the orange peel by other methods as high voltage electrical discharges [6], microwave-assisted extraction [27], and pressurized liquid extraction [3], but they noticed lower yields compared to our results (Table 4). The ultrasound-assisted extraction of phenolic compounds from orange peel using ultrasonic bath has been performed by several authors using ethanol $[3,28,29]$ or acetone [27], obtaining extraction times quite similar to our optimum one. In addition, some pre-treatments have been performed by other authors in orange by-products for enhancing the extraction of phenolic compounds. On the one hand, Shahram et al. [30] improved the usual ultrasonic bath extraction combining it with an enzymatic process. However, the TPC seemed to be lower than the previous studies without enzymes. Overall, it required longer times because of the lower $\mathrm{pH}$. In addition, pectinases are vegetal cells, and the ultrasonic waves can damage them, making them to lose their potential effect. In spite of the fact that they did not achieve a high yield, it could be had into account for future studies making slightly modifications. On the other hand, Luengo et al. [31] studied for the first time the use of pulsed electric fields as pretreatment, obtaining an increment of $23 \%$ in the yield in front of the samples directly submitted to 
pressing extraction. Another interesting pre-treatment was the one carried out in orange peel by El-Kantar et al. [32], who achieved an improvement of extraction about $47 \%$ using infrared radiation previously to the conventional water extraction. Although the final results obtained were not satisfactory, these two pre-treatments also ought to be had into account for future studies combining with this optimized sonotrode-assisted extraction.

Table 4. Previous research about other technologies used for extracting phenolic compounds from the orange by-products with the conditions used and the total phenolic compounds (TPC) obtained.

\begin{tabular}{|c|c|c|c|}
\hline Technology Used & Conditions & TPC (mg GAE/g d.w.) & Reference \\
\hline \multirow{6}{*}{ Solvent extraction } & Water, $60^{\circ} \mathrm{C}, 12 \mathrm{~h}$ & 6.89 & [33] \\
\hline & Methanol, $55^{\circ} \mathrm{C}, 3 \mathrm{~h}$ & 28.00 & [25] \\
\hline & Methanol/water $80: 20,20^{\circ} \mathrm{C}, 22 \mathrm{~h}$ & 25.60 & [26] \\
\hline & Methanol/sample $20: 1(v / w), 25^{\circ} \mathrm{C}, 72 \mathrm{~h}$ & 18.50 & [34] \\
\hline & Acetone/sample $20: 1(v / w), 25{ }^{\circ} \mathrm{C}, 72 \mathrm{~h}$ & 18.00 & [34] \\
\hline & Acetone $50 \% /$ sample $50: 1(v / w), 60^{\circ} \mathrm{C}, 2 \mathrm{~h}$ & 10.21 & [27] \\
\hline $\begin{array}{l}\text { High voltage electrical } \\
\text { discharges-assisted extraction }\end{array}$ & Water/sample $20: 10(v / w), 50^{\circ} \mathrm{C}, 200 \mathrm{~kJ} / \mathrm{kg} 0,5 \mathrm{~Hz}$ & 7.00 & [6] \\
\hline \multirow{4}{*}{$\begin{array}{l}\text { Ultrasound-assisted extraction } \\
\text { (ultrasonic bath) }\end{array}$} & Ethanol $40 \%$ / sample 80:1 $(v / w), 40{ }^{\circ} \mathrm{C}, 30 \mathrm{~min}, 150 \mathrm{~W}$ & 2.33 & [29] \\
\hline & Ethanol $50 \% /$ sample $57: 1(v / w), 30^{\circ} \mathrm{C}, 15 \mathrm{~min}$ & 5.50 & [3] \\
\hline & Ethanol 50\%/sample 10:1 (v/w), $30 \mathrm{~min}, 400 \mathrm{~W}$ & 1.05 & [28] \\
\hline & $\begin{array}{l}\text { Acetone } 75.79 \% \text { / sample } 50: 1(v / w), 27^{\circ} \mathrm{C}, 8.33 \mathrm{~min}, \\
65.94 \% \text { amplitude }\end{array}$ & 10.35 & [27] \\
\hline Microwave-assisted extraction & Acetone $51 \%$ /sample $25: 1(v / w), 122 \mathrm{~s}, 500 \mathrm{~W}$ & 12.20 & [27] \\
\hline Pressurized liquid extraction & Ethanol 50\%/sample $47: 1(v / w), 10 \mathrm{MPa}, 65^{\circ} \mathrm{C}, 40 \mathrm{~min}$ & 10.30 & [3] \\
\hline $\begin{array}{l}\text { Ultrasound-assisted extraction } \\
\text { (ultrasonic bath) combined } \\
\text { with enzymatic process }\end{array}$ & $\begin{array}{c}\text { Ethanol/sample } 10: 1(v / w), 25^{\circ} \mathrm{C}, 120 \mathrm{~min}, 500 \mathrm{~W} \text {, with } \\
\text { pectinase } 0.50 \% w / w \text { at } \mathrm{pH} 4\end{array}$ & 0.88 & {$[30]$} \\
\hline $\begin{array}{l}\text { Pressing extraction with } \\
\text { pulsed electric fields as } \\
\text { pre-treatment }\end{array}$ & $7 \mathrm{kV} / \mathrm{cm}$ PEF and 5 bars, $30 \mathrm{~min}$ & 0.35 & {$[31]$} \\
\hline $\begin{array}{l}\text { Solvent extraction with } \\
\text { infrared as pre-treatment }\end{array}$ & Ethanol $50 \%$ /sample $8: 1(v / w), 50^{\circ} \mathrm{C}, 1.5 \mathrm{~h}$ & 1.5 & [32] \\
\hline
\end{tabular}

Bringing into account the antioxidant assays, the optimal results obtained were $26.37 \pm 1.6$ and $35.62 \pm 2.1 \mathrm{mg}$ TE/g d.w. for the DPPH and ABTS, respectively. DPPH technique has been mostly used in bibliography in this kind of matrix. Comparing results, the optimal value obtained for DPPH is higher than those obtained by HernándezCarranza et al. [33] (8.94 mg TE/g d.w.) and Barrales et al. [3] (4.30 mg TE/g d.w.). However, Lachos-Pérez et al. [35] got an optimal result slightly higher (26.78 mg TE/g d.w.) but with a time of extraction of $2 \mathrm{~h}$, much higher that the optimized value obtained in this study.

\subsection{Analytical Parameters of the Method}

Five calibration curves were made in order to quantify the phenolic compounds identified in the orange by-product. The curves were made of vanillic acid, chlorogenic acid, ferulic acid, quercetin, and rutin. In Table 5 are contained the standards used, the calibration ranges and curves, the regression coefficients, and the limits of detection (LOD) and of quantification (LOQ). 
Table 5. Standard analytes used for elaborating the calibration curves with the range used, equations, $R^{2}$, LOD, and LOQ of each compound.

\begin{tabular}{cccccc}
\hline Standards & $\begin{array}{c}\text { Calibration } \\
\text { Ranges }(\mu \mathrm{g} / \mathbf{m L})\end{array}$ & $\begin{array}{c}\text { Calibration Curves } \\
(\mu \mathrm{g} / \mathbf{m L})\end{array}$ & $\boldsymbol{R}^{\mathbf{2}}$ & $\begin{array}{c}\text { LOD } \\
(\mu \mathrm{g} / \mathbf{m L})\end{array}$ & $\begin{array}{c}\text { LOQ } \\
(\mu \mathrm{g} / \mathbf{m L})\end{array}$ \\
\hline Vanillic acid & $3.7-236.67$ & $y=21.069 x+197.15$ & 0.9979 & 0.47 & 1.57 \\
Chlorogenic acid & $3.85-246.67$ & $y=58.665 x-289.54$ & 0.9984 & 0.17 & 0.56 \\
Ferulic acid & $3.54-226.67$ & $y=37.071 x+155.61$ & 0.9983 & 0.27 & 0.89 \\
Quercetin & $3.54-226.67$ & $y=154.26 x+1309.1$ & 0.9988 & 0.06 & 0.21 \\
Rutin & $3.44-220$ & $y=239.6 x+690.3$ & 0.9954 & 0.04 & 0.14 \\
\hline
\end{tabular}

The calibration curves were elaborated by using the peak areas of each standard measured by HPLC at different concentrations. Calibration ranges were determined previously according to the LOQ values. The regression coefficients were $>0.99$ in all cases which means that all calibration curves had good linearity. LOD ranged between 0.04 and $0.47 \mu \mathrm{g} / \mathrm{mL}$, and LOQ between 0.14 and $1.57 \mu \mathrm{g} / \mathrm{mL}$.

\subsection{Identification of Phenolic Compounds by HPLC-ESI-TOF-MS}

The optimal conditions of extractions were applied to extract the phenolic compounds from fresh and dried orange by-products in order to evaluate the effect of the drying step. The extracts were characterized by HPLC-MS and a total of seventy-four compounds were identified; forty-four were flavonoids, fourteen phenolic acids, fourteen terpenoids, and two other polar compounds.

All the identified compounds are described in Table 6 with their retention time, molecular formula, experimental and calculated $\mathrm{m} / \mathrm{z}$, score and error (ppm). For ensuring the mass accuracy, the tolerances chosen had a score higher than $85 \%$ and error lower than $5 \mathrm{ppm}$. To identify the compounds the generated molecular formula and some in source fragments were checked and studied comparing also with different databases such as PUBCHEM, Phenol-Explorer and literature.

Phenolic acids. Thirteen hydroxycinnamic acids and one hydroxybenzoic acid have been found.

Five caffeic acid derivates (peaks 1, 7, 13, 14, and 23) have been detected in this study. Two of them, at $m / z 251$ (peaks 1 and 3), have been tentatively identified as caffeoylglycolic acid methyl esters isomers a and $b$. This compound was first reported in leaves of Parthenocissus tricuspidate by Saleem et al. [36]. Another two derivatives at $\mathrm{m} / \mathrm{z}$ 295 are named as caffeoylmalic acids isomers corresponding to peaks 14 and 23 described previously in plants by Hahn et al. [37], being the major source the lettuce. Moreover, the last derivate of caffeic acid that correspond to the compound found at peak 7 has been assigned to caffeic acid 3-O-glucuronide according to Tang et al. [38], who found the compound in hops extracts. To our knowledge, there are not previous references of these compounds found in citrus neither in orange matrixes; however, caffeic acid is a well-known compound found in orange peel by some authors [39,40].

Peaks 5, 6, and 10, with molecular formula $\mathrm{C}_{16} \mathrm{H}_{18} \mathrm{O}_{11}$, were identified as 2-(E)-Oferuloyl-D-galactaric acids isomers $\mathrm{a}, \mathrm{b}$ and $\mathrm{c}$ first identified in orange peel extracts by Risch et al. [41].

Derivatives of ferulic and sinapic acids have been identified in the peaks 9 and 12, tentatively named as ferulic acid $O$-glucoside and sinapic acid $O$-glucoside, respectively. It seems to be in concordance with Lu et al. [42] who identified in orange pulp a mixture of ferulic acid and sinapic acid glucosides. In addition, both acids have been previously described in orange peel by other authors [27], but not these glucoside derivatives. 
Table 6. Compounds identified by HPLC-ESI-TOF-MS in the optimal extract of orange peel.

\begin{tabular}{|c|c|c|c|c|c|c|c|}
\hline No. & Compound & $\begin{array}{l}\text { Retention Time } \\
\text { (Min) }\end{array}$ & $\begin{array}{l}\text { Molecular } \\
\text { Formula }\end{array}$ & $m / z$ Experimental & $m / z$ Calculated & Score & Error (ppm) \\
\hline 1 & Caffeoylglycolic acid methyl ester isomer a & 3.608 & $\mathrm{C}_{12} \mathrm{H}_{12} \mathrm{O}_{6}$ & 251.055 & 251.0556 & 86.53 & -2.4 \\
\hline 2 & Norbergenin & 3.806 & $\mathrm{C}_{13} \mathrm{H}_{14} \mathrm{O}_{9}$ & 313.0563 & 313.056 & 94.08 & 1 \\
\hline 3 & Citric acid & 4.278 & $\mathrm{C}_{6} \mathrm{H}_{8} \mathrm{O}_{7}$ & 191.0198 & 191.0192 & 94.52 & 3.1 \\
\hline 4 & Cynaroside A & 4.774 & $\mathrm{C}_{21} \mathrm{H}_{32} \mathrm{O}_{10}$ & 443.191 & 443.1917 & 99.27 & -1.6 \\
\hline 5 & 2-(E)-O-Feruloyl-D-galactaric acid isomer a & 4.898 & $\mathrm{C}_{16} \mathrm{H}_{18} \mathrm{O}_{11}$ & 385.0769 & 385.0771 & 99.77 & -0.5 \\
\hline 7 & Caffeic acid 3-O-glucuronide & 5.308 & $\mathrm{C}_{15} \mathrm{H}_{16} \mathrm{O}_{10}$ & 355.0667 & 355.0665 & 99.92 & 0.6 \\
\hline 8 & Citroside & 5.669 & $\mathrm{C}_{19} \mathrm{H}_{30} \mathrm{O}_{8}$ & 385.1856 & 385.1862 & 87.14 & -1.6 \\
\hline 9 & Ferulic acid $O$-glucoside & 5.854 & $\mathrm{C}_{16} \mathrm{H}_{20} \mathrm{O}_{9}$ & 355.1024 & 355.1029 & 97.78 & -1.4 \\
\hline 10 & 2-(E)-O-Feruloyl-D-galactaric acid isomer c & 6.007 & $\mathrm{C}_{16} \mathrm{H}_{18} \mathrm{O}_{11}$ & 385.0768 & 385.0771 & 96.52 & -0.8 \\
\hline 11 & Feruloyl isocitric acid isomer a & 6.131 & $\mathrm{C}_{16} \mathrm{H}_{16} \mathrm{O}_{10}$ & 367.0662 & 367.0665 & 99.75 & -0.8 \\
\hline 12 & Sinapic acid $O$-glucoside & 6.206 & $\mathrm{C}_{17} \mathrm{H}_{22} \mathrm{O}_{10}$ & 385.1133 & 385.1136 & 99.70 & -0.5 \\
\hline 14 & Caffeoylmalic acid isomer a & 6.45 & $\mathrm{C}_{13} \mathrm{H}_{12} \mathrm{O}_{8}$ & 295.0446 & 295.0454 & 98.46 & -2.7 \\
\hline 15 & Sinapinic acid-O-glucuronide & 6.545 & $\mathrm{C}_{17} \mathrm{H}_{20} \mathrm{O}_{11}$ & 399.0921 & 399.0927 & 89.58 & -1.5 \\
\hline 16 & Feruloyl isocitric acid isomer $b$ & 6.661 & $\mathrm{C}_{16} \mathrm{H}_{16} \mathrm{O}_{10}$ & 367.0675 & 367.0665 & 90.04 & 2.7 \\
\hline 17 & Rutin isomer a & 6.785 & $\mathrm{C}_{27} \mathrm{H}_{30} \mathrm{O}_{16}$ & 609.1467 & 609.1456 & 94.51 & 1.8 \\
\hline 18 & Dihydroisorhamnetin 7-rutinoside & 7.194 & $\mathrm{C}_{28} \mathrm{H}_{34} \mathrm{O}_{16}$ & 625.1765 & 625.1769 & 87.24 & -0.6 \\
\hline 19 & Apigenin-di-C-hexoside (Vicenin-2) isomer a & 7.376 & $\mathrm{C}_{27} \mathrm{H}_{30} \mathrm{O}_{15}$ & 593.1506 & 593.1506 & 99.24 & 0 \\
\hline 20 & Prunin & 7.596 & $\mathrm{C}_{21} \mathrm{H}_{22} \mathrm{O}_{10}$ & 433.1132 & 433.1135 & 100.0 & -0.7 \\
\hline 21 & Isorhamnetin-3-O-rutinoside isomer a & 7.753 & $\mathrm{C}_{28} \mathrm{H}_{32} \mathrm{O}_{16}$ & 623.1607 & 623.1612 & 96.55 & -0.8 \\
\hline 22 & Isorhamnetin-3-O-rutinoside isomer b & 7.914 & $\mathrm{C}_{28} \mathrm{H}_{32} \mathrm{O}_{16}$ & 623.1605 & 623.1612 & 95.79 & -1.1 \\
\hline 23 & Caffeoylmalic acid isomer $b$ & 8.241 & $\mathrm{C}_{13} \mathrm{H}_{12} \mathrm{O}_{8}$ & 295.0428 & 295.0454 & 88.92 & -8.8 \\
\hline 24 & Luteolin- $C$-hexoside- $C$-pentoside isomer a & 8.432 & $\mathrm{C}_{26} \mathrm{H}_{28} \mathrm{O}_{15}$ & 579.134 & 579.135 & 86.57 & -1.7 \\
\hline
\end{tabular}


Table 6. Cont.

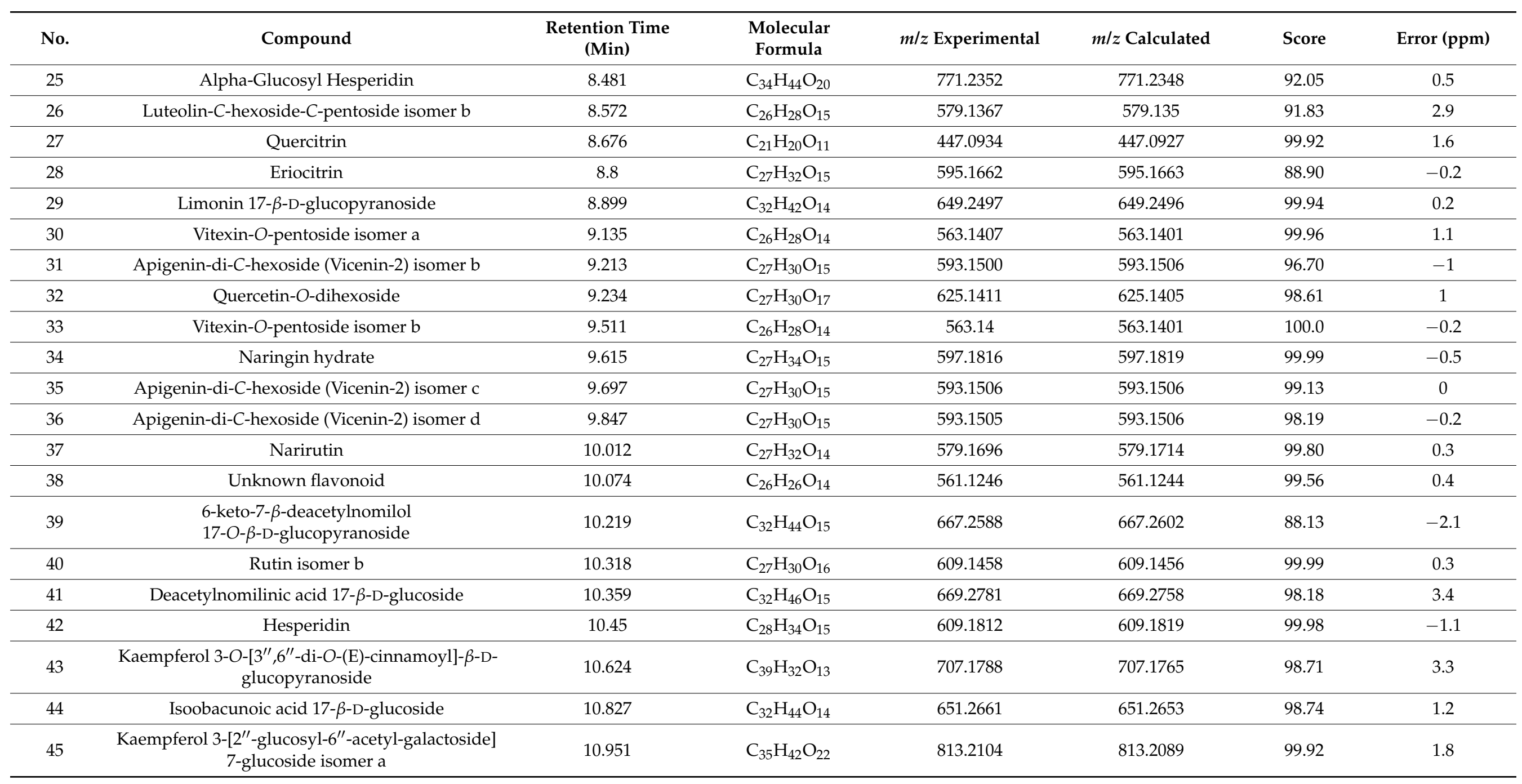


Table 6. Cont

\begin{tabular}{|c|c|c|c|c|c|c|c|}
\hline No. & Compound & $\begin{array}{l}\text { Retention Time } \\
\text { (Min) }\end{array}$ & $\begin{array}{l}\text { Molecular } \\
\text { Formula }\end{array}$ & $m / z$ Experimental & $m / z$ Calculated & Score & Error (ppm) \\
\hline 46 & $\begin{array}{c}\text { Kaempferol 3-[2" } 2^{\prime \prime} \text { glucosyl- } 6^{\prime \prime} \text {-acetyl-galactoside] } \\
\text { 7-glucoside isomer b }\end{array}$ & 11.063 & $\mathrm{C}_{35} \mathrm{H}_{42} \mathrm{O}_{22}$ & 813.2089 & 813.2089 & 97.06 & 0.2 \\
\hline 47 & Apigenin-di-C-hexoside (Vicenin-2) isomer e & 11.208 & $\mathrm{C}_{27} \mathrm{H}_{30} \mathrm{O}_{15}$ & 593.1504 & 593.1506 & 99.92 & -0.3 \\
\hline 48 & Isorhamnetin-3-O-rutinoside isomer c & 11.336 & $\mathrm{C}_{28} \mathrm{H}_{32} \mathrm{O}_{16}$ & 623.1614 & 623.1612 & 99.20 & 0.3 \\
\hline 49 & Kaempferol-dihexosyl acetate & 11.613 & $\mathrm{C}_{29} \mathrm{H}_{32} \mathrm{O}_{17}$ & 651.1577 & 651.1571 & 86.35 & 2.5 \\
\hline 50 & nomilin $17-O-\beta$-D-glucopyranoside & 11.973 & $\mathrm{C}_{34} \mathrm{H}_{46} \mathrm{O}_{15}$ & 693.2766 & 693.2758 & 99.99 & 1.2 \\
\hline 51 & Neohesperidin & 12.184 & $\mathrm{C}_{28} \mathrm{H}_{34} \mathrm{O}_{15}$ & 609.1824 & 609.1819 & 99.90 & 0.8 \\
\hline 52 & Didymin & 12.41 & $\mathrm{C}_{28} \mathrm{H}_{34} \mathrm{O}_{14}$ & 593.1885 & 593.187 & 91.36 & 2.5 \\
\hline 53 & Nomilinic acid 17- $\beta$-D-glucoside & 12.602 & $\mathrm{C}_{34} \mathrm{H}_{48} \mathrm{O}_{16}$ & 711.2878 & 711.2864 & 97.47 & 2 \\
\hline 54 & Apigenin 7-O-neohesperidoside & 12.693 & $\mathrm{C}_{27} \mathrm{H}_{30} \mathrm{O}_{14}$ & 577.1564 & 577.1557 & 99.80 & 1.2 \\
\hline 55 & Obacunone 17- $\beta$-D-glucoside & 12.742 & $\mathrm{C}_{32} \mathrm{H}_{42} \mathrm{O}_{13}$ & 633.2574 & 633.2547 & 87.20 & 4.3 \\
\hline 56 & Naringin $6^{\prime \prime}$-malonate & 13.094 & $\mathrm{C}_{30} \mathrm{H}_{34} \mathrm{O}_{17}$ & 665.1697 & 665.1718 & 90.41 & -3.2 \\
\hline 58 & Kaempferol 3-apiosyl-(1->4)-rhamnoside-7-rhamnoside & 13.338 & $\mathrm{C}_{32} \mathrm{H}_{38} \mathrm{O}_{18}$ & 709.1987 & 709.198 & 91.26 & 1 \\
\hline 59 & Quercetin-3-O-rutinoside-7-O-Glucoside & 13.814 & $\mathrm{C}_{33} \mathrm{H}_{40} \mathrm{O}_{21}$ & 771.2137 & 771.1984 & 89.33 & 1.8 \\
\hline 60 & Demethylnobiletin & 13.888 & $\mathrm{C}_{20} \mathrm{H}_{20} \mathrm{O}_{8}$ & 387.1079 & 387.108 & 92.26 & -0.3 \\
\hline 61 & $\begin{array}{c}\text { Methyl 2-[(2S,4R,5S,6R)-4-acetyloxy-6-(acetyloxymethyl)- } \\
\text { 5-[(2R,4R,5S,6R)-4,5-diacetyloxy-6-(acetyloxymethyl) } \\
\text { oxan-2-yl]oxyoxan-2-yl]oxy-3,4,5-trihydroxy-6- } \\
\text { oxobenzo[7]annulene-8-carboxylate }\end{array}$ & 14.132 & $\mathrm{C}_{35} \mathrm{H}_{40} \mathrm{O}_{20}$ & 779.2047 & 779.2035 & 99.98 & 1.5 \\
\hline 62 & Naringenin & 14.178 & $\mathrm{C}_{15} \mathrm{H}_{12} \mathrm{O}_{5}$ & 271.0603 & 271.0606 & 95.40 & -1.1 \\
\hline 63 & $\begin{array}{c}\text { Kaempferol 3-O-sinapoyl-caffeoyl-sophoroside } \\
\text { 7-O-glucoside isomer a }\end{array}$ & 14.339 & $\mathrm{C}_{53} \mathrm{H}_{56} \mathrm{O}_{28}$ & 1139.2892 & 1139.2885 & 95.98 & 1.1 \\
\hline 64 & $\begin{array}{c}\text { Kaempferol 3-O-sinapoyl-caffeoyl-sophoroside } \\
\text { 7-O-glucoside isomer b }\end{array}$ & 14.476 & $\mathrm{C}_{53} \mathrm{H}_{56} \mathrm{O}_{28}$ & 1139.2933 & 1139.288 & 88.40 & 4.7 \\
\hline 65 & Deacetylnomilin acid & 14.526 & $\mathrm{C}_{26} \mathrm{H}_{34} \mathrm{O}_{9}$ & 489.2131 & 489.2125 & 90.73 & 1.2 \\
\hline
\end{tabular}


Table 6. Cont.

\begin{tabular}{|c|c|c|c|c|c|c|c|}
\hline No. & Compound & $\begin{array}{l}\text { Retention Time } \\
\text { (Min) }\end{array}$ & $\begin{array}{l}\text { Molecular } \\
\text { Formula }\end{array}$ & $m / z$ Experimental & $m / z$ Calculated & Score & Error (ppm) \\
\hline 66 & Limonol & 14.559 & $\mathrm{C}_{26} \mathrm{H}_{32} \mathrm{O}_{8}$ & 471.2025 & 471.2019 & 96.48 & 1.3 \\
\hline 67 & $\begin{array}{l}\text { Kaempferol 3-O-feruloyl-caffeoyl-sophoroside } \\
\text { 7-O-glucoside }\end{array}$ & 14.786 & $\mathrm{C}_{52} \mathrm{H}_{54} \mathrm{O}_{27}$ & 1109.2789 & 1109.2774 & 90.94 & 1.4 \\
\hline 68 & Epilimonin & 15.043 & $\mathrm{C}_{26} \mathrm{H}_{30} \mathrm{O}_{8}$ & 469.1859 & 469.1862 & 99.98 & -0.6 \\
\hline 69 & Limonin & 15.708 & $\mathrm{C}_{26} \mathrm{H}_{30} \mathrm{O}_{8}$ & 469.1849 & 469.1862 & 99.28 & -2.8 \\
\hline 71 & Pectolinarigenin & 16.073 & $\mathrm{C}_{17} \mathrm{H}_{14} \mathrm{O}_{6}$ & 313.0704 & 313.0712 & 98.95 & -2.6 \\
\hline 72 & Deoxylimonin & 16.102 & $\mathrm{C}_{26} \mathrm{H}_{30} \mathrm{O}_{7}$ & 453.1881 & 453.1913 & 85.92 & -3.1 \\
\hline 73 & Isosakuranetin & 16.524 & $\mathrm{C}_{16} \mathrm{H}_{14} \mathrm{O}_{5}$ & 285.0754 & 285.0763 & 89.61 & -3.2 \\
\hline 74 & $3^{\prime}, 4^{\prime}$-Didemethylnobiletin & 16.569 & $\mathrm{C}_{19} \mathrm{H}_{18} \mathrm{O}_{8}$ & 373.0923 & 373.0923 & 94.17 & 0 \\
\hline
\end{tabular}


At time 6.545 (peak 15) another hydroxycinnamic acid has been tentatively identified as a sinapinic acid derivate according with Anagnostopoulou et al. [43] and Bocco et al. [44] namely as sinapinic acid-O-glucuronide described in orange peels.

The compounds found at peaks 11 and 16 with molecular formula $\mathrm{C}_{16} \mathrm{H}_{16} \mathrm{O}_{10}$, have been identified as feruloyl isocitric acid isomers, described previously in plants by Masike et al. [45], and never described before in orange peel extracts. However, isocitric acid has been previously found in citrus peel matrices [46]. Furthermore, the ratio citric/isocitric acids usually is used for quality control in the orange juice; in fact, a ratio higher than 130 usually suggests that the beverage has been correcting by adding citric acid [47].

Finally, a hydroxybenzoic acid has been identified at time 3.806 min (peak 2). According with Nazir et al. [48] it was tentatively named as norbergenin. They identified this compound from Bergenia stracheyi, but there are no references in citrus matrices.

Flavonoids. As a majoritarian group, forty-four flavonoids have been identified in the orange peel.

Peaks $28,37,42,51,52$ and 62 were assigned to flavanone compounds corresponding to eriocitrin, narirutin, hesperidin, neohesperidin, didymin, and naringenin, respectively. Moreover, rutin isomers have been found at $m / z 609$ (peaks 17 and 40). These compounds are in agreement with several authors who identified them in orange peel [39,49-56].

With a molecular formula $\mathrm{C}_{21} \mathrm{H}_{22} \mathrm{O}_{10}$ (peak 20), the flavonoid prunin has been identified in concordance with Berhow et al. [57] and Castillo et al. [58], who found it for the first times as a precursor of neohesperidin and naringin in citrus matrices.

According with Oboh et al. [54] and Omoba et al. [56] the compound found at time $8.676 \mathrm{~min}$ (peak 27) was identified as quercitrin, found in orange's juices and peels, respectively.

Two flavonoid isomers with $\mathrm{m} / z 563$ and molecular formula $\mathrm{C}_{26} \mathrm{H}_{28} \mathrm{O}_{14}$ have been found (peaks 30 and 33) and they were assigned to vitexin-O-pentoside according to Fayek et al. [59] who found this compound in Citrus reticulata peel. It also could be an apigenin derivate called apigenin 6-C-glucoside 8-C-arabinoside in concordance with Lu et al. [42] who found a similar compound (apigenin-6,8-di-C-glucoside) in an orange variety.

At retention time $16.524 \mathrm{~min}$ (peak 73), and according with Gattuso et al. [60], it has been identified the flavonoid as isosakuranetin, previously found in orange juice. This compound has been found for the first time in Citrus reticulata peel by Fayek et al. [59], and they named it as dihydroxy-methoxyflavanone, so it is the first time this compound is identified in orange by-products.

Two nobiletin derivates has been found at times 13.88 and $16.57 \mathrm{~min}$ (peaks 60 and 74). According with Goh et al. [61], they were tentatively identified as demethylnobiletin and $3^{\prime}, 4^{\prime}$-didemethylnobiletin, respectively, described in the orange peel.

A hesperidin derivate, alpha-glucosyl hesperidin, previously found in the orange peel by several authors [62-66] has been identified at time 8.481 min (peak 25). In addition, a naringin derivate found at peak 34 was assigned to naringin hydrate according with Iglesias-Carres et al. [55] and Fayek et al. [59].

Isorhamnetin-3-O-rutinoside isomers were identified (peaks 21, 22 and 48) with $\mathrm{m} / \mathrm{z}$ 623. At $7.194 \mathrm{~min}$ (peak 18), the detected signal was identified as dihydroisorhamnetin-7rutinoside. In addition, the compounds found at times 12.693 and 13.814 min (peaks 54 and 59), were identified as apigenin-7-O-neohesperidoside and quercetin-3-O-rutinoside-7$O$-glucoside, respectively. The present data is in agreement with Abad-García et al. [67] who identified fifty-eight new compounds in citrus juices.

Compounds 19, 31, 35, 36, and 47 presented the same mass (593) and molecular formula $\left(\mathrm{C}_{27} \mathrm{H}_{30} \mathrm{O}_{15}\right)$, and could be identified as apigenin-di-C-hexoside (Vicenin-2) according with Fayek et al. [59] who found this compound in Citrus sinensis peel and identified it according with Brito et al. [68], who previously detected vicenin-2 in Citrus aurantiifolia.

The compounds with molecular formula $\mathrm{C}_{26} \mathrm{H}_{28} \mathrm{O}_{15}$ (peaks 24 and 26) can be identified as luteolin- $C$-hexoside- $C$-pentoside isomers characterized for the first time by Fayek et al. [59] in Citrus sinensis peel according to Roriz et al. [69] who described the compound in Cymbopogon citratus. 
Six kaempferol derivates were found. The first one kaempferol derivate with a formula $\mathrm{C}_{39} \mathrm{H}_{32} \mathrm{O}_{13}$ (peak 43), was tentatively named as kaempferol 3-O-[3", $6^{\prime \prime}$-di-O(E)-cinnamoyl]- $\beta$-D-glucopyranoside. The second one with $\mathrm{m} / \mathrm{z} 813$ (peaks 45 and 46) was tentatively named as kaempferol-3-[2"-glucosyl-6" -acetyl-galactoside]-7-glucoside. Previously, this compound had been detected only in herbs and spices, but not quantified [70]. The third and fourth ones (peaks 57 and 58) with $\mathrm{m} / \mathrm{z} 635.1617$ and 709.1987 are kaempferol 3-O-(6"-O-acetyl) glucoside-7-O-rhamnoside, and kaempferol 3-apiosyl-(1$>4$ )-rhamnoside-7-rhamnoside, respectively. The fifth derivate is kaempferol-3-O-sinapoylcaffeoyl-sophoroside-7-O-glucoside with molecular formula $\mathrm{C}_{53} \mathrm{H}_{56} \mathrm{O}_{28}$ (peaks 63 and 64 respectively). The sixth one was found at time $14.786 \mathrm{~min}$ (peak 67) and is kaempferol-3-Oferuloyl-caffeoyl-sophoroside-7-O-glucoside. All this compounds have been tentatively identified based on other kaempferol derivates found in other plant sources [71,72]. Although kaempferol derivates are known to be present in citrus peels, no previous references have been found, neither in orange peel.

With a mass $(\mathrm{m} / \mathrm{z}) 443$ (peak 4), this flavonoid has never been described in the orange peel, nor in the citrus family so far. However, according to Zanzer et al. [73], this compound was characterized before in black pepper, so it has been tentatively identified as cynaroside A.

The flavonoid with formula $\mathrm{C}_{27} \mathrm{H}_{30} \mathrm{O}_{17}$ (peak 32) was tentatively identified as quercetin$\mathrm{O}$-dihexoside as Fayek et al. [59] found it previously in Citrus reticulata and Citrus sinensis peels.

With a mass of 651, at 11.613 min (peak 49) the flavonoid found can be named as kaempferol-dihexosyl acetate according to Fayek et al. [59], who recently found it from Citrus aurantiifolia peel for the first time.

At time $10.074 \mathrm{~min}$ and with a mass of 561 (peak 38), a controversial compound was identified. According with Fayek et al. [59], this compound could be an unknown flavonoid, as they found it in Citrus paradisi peel. Although no other references have been found in citrus matrixes, for the context this affirmation can be accepted.

The compound naringin $6^{\prime \prime}$-malonate (peak 56) was tentatively identified according with Berhow et al. [74] who found this compound and other malonic acid ester derivatives of naringin for the first time in grapefruit. Kanes et al. [75] found this compound in some rutaceae citrus species, but no references has been found related to orange peel.

With a molecular formula $\mathrm{C}_{17} \mathrm{H}_{14} \mathrm{O}_{6}$ (peak 71) this compound has been assigned to pectolinarigenin according with Cheriet et al. [76] who described it in several plants and fruits as oranges. However, this compound has been previously named in Citrus sinensis peel by Fayek et al. [59] as dihydroxy-dimethoxyflavone, previously identified in Citrus reticulata peel by Yang et al. [77].

Terpenoids. Talking about the terpenoids, 13 limonoids have been identified. They have been identified according with Gualdani et al. [78] and Shi et al. [79], who characterized limonoids from several citrus species and matrixes including orange peel. The compounds found are named limonin 17- $\beta$-D-glucopyranoside, 6-keto-7- $\beta$-deacetylnomilol 17-O- $\beta$ D-glucopyranoside, deacetylnomilinic acid-17- $\beta$-D-glucoside, isoobacunoic acid 17- $\beta$-Dglucoside, nomilin 17-O- $\beta$-D-glucopyranoside, nomilinic acid $17-\beta$-D-glucoside, obacunone 17- $\beta$-D-glucoside, deacetylnomilin acid, limonol, epilimonin, limonin, nomilinic acid, and deoxylimonin (peaks 29, 39, 41, 44, 50, 53, 55 65, 66, 68, 69, 70 and 72, respectively). Another terpene different from those, a sesquiterpene, has been found at $5.7 \mathrm{~min}$ (peak 8). According to Umehara et al. [80], it was tentatively identified as citroside. They found this compound from leaves of Citrus unshiu.

Other polar compounds. Finally, other two polar compounds have been found in the orange by-product. The ion found at $m / z 191.0198$ (peak 3) at $4.278 \mathrm{~min}$, is well known as citric acid, and according to Liew et al. [81], it has been previously identified in orange peel extracts. Meanwhile the other compound (peak 61) with the molecular formula $\mathrm{C}_{35} \mathrm{H}_{40} \mathrm{O}_{20}$ was only found match with the compound methyl 2-[(2S,4R,5S,6R)-4acetyloxy-6-(acetyloxymethyl)-5-[(2R,4R,5S,6R)-4,5-diacetyloxy-6-(acetyloxymethyl) oxan- 
2-yl] oxyoxan-2-yl] oxy-3,4,5-trihydroxy-6-oxobenzo [7] annulene-8-carboxylate that no has previous references.

\subsection{Quantification of Phenolic Compounds in Orange Peel Extracts}

A total of 14 phenolic acids and 44 flavonoids were quantified in orange by-product optimal extracts (Table 7).

Table 7. Quantification of phenolic compounds from orange peel dry and fresh by HPLC-MS (expressed as mean \pm standard deviation $\mu \mathrm{g} / \mathrm{g}$ d.w.).

\begin{tabular}{|c|c|c|}
\hline Compounds & $\begin{array}{l}\text { Fresh By-Product } \\
\quad(\mu \mathrm{g} / \mathrm{g} \text { d.w. })\end{array}$ & $\begin{array}{l}\text { Dry By-Product } \\
(\mu \mathrm{g} / \mathrm{g} \text { d.w.) }\end{array}$ \\
\hline Sum of phenolic compounds & $6344.0 \pm 3.6$ & $4737.6 \pm 4.4$ \\
\hline Phenolic Acids & $3087.5 \pm 0.2$ & $2891.1 \pm 2.4$ \\
\hline Norbergenin & $383.5 \pm 0.5$ & $340.4 \pm 0.7$ \\
\hline Caffeoylglycolic acid methyl ester isomer a & $201.8 \pm 0.1$ & $284.2 \pm 0.7$ \\
\hline Caffeoylglycolic acid methyl ester isomer $b$ & $133.36 \pm 0.04$ & $178.2 \pm 0.1$ \\
\hline Caffeic acid 3-O-glucuronide & $218.9 \pm 0.3$ & $128.6 \pm 0.7$ \\
\hline Caffeoylmalic Acid isomer a & $127.9 \pm 0.6$ & $99.5 \pm 0.4$ \\
\hline Caffeoylmalic Acid isomer b & $109.5 \pm 0.1$ & $77.6 \pm 0.1$ \\
\hline 2-(E)-O-Feruloyl-D-galactaric acid isomer a & $378.8 \pm 0.5$ & $463.0 \pm 0.04$ \\
\hline 2-(E)-O-Feruloyl-D-galactaric acid isomer b & $575.6 \pm 0.3$ & $416.3 \pm 0.4$ \\
\hline 2-(E)-O-Feruloyl-D-galactaric acid isomer c & $313.2 \pm 0.2$ & $564.0 \pm 0.9$ \\
\hline Ferulic acid $O$-glucoside & $235.3 \pm 0.7$ & $48.73 \pm 0.1$ \\
\hline Feruloyl Isocitric acid isomer a & $195.2 \pm 0.7$ & $170.66 \pm 0.4$ \\
\hline Feruloyl isocitric acid isomer $b$ & $16.9 \pm 0.03$ & $11.2 \pm 0.2$ \\
\hline Sinapic acid $O$-glucoside & $183.5 \pm 0.4$ & $14.9 \pm 0.1$ \\
\hline Sinapinic acid-O-glucuronide & $14.0 \pm 0.5$ & $93.7 \pm 0.1$ \\
\hline Flavonoids & $3256.5 \pm 3.4$ & $1846.5 \pm 2.0$ \\
\hline Cynaroside A & $13.1 \pm 0.3$ & $6.1 \pm 0.1$ \\
\hline Rutin isomer a & $57.8 \pm 0.3$ & $73.6 \pm 0.1$ \\
\hline Rutin isomer b & $22.0 \pm 0.1$ & $49.8 \pm 0.05$ \\
\hline Prunin & $122.5 \pm 0.4$ & $35.4 \pm 0.01$ \\
\hline Quercitrin & $1.2 \pm 0.2$ & $<$ LOQ \\
\hline Eriocitrin & $24.6 \pm 0.1$ & $17.5 \pm \hat{0.4}$ \\
\hline Narirutin & $799.4 \pm 0.5$ & $319.6 \pm 0.4$ \\
\hline Hesperidin & $894.8 \pm 0.5$ & $320.2 \pm 0.5$ \\
\hline$\alpha$-glucosyl Hesperidin & $23.8 \pm 0.1$ & $19.0 \pm 0.1$ \\
\hline Neohesperidin & $<$ LOQ & $<$ LOQ \\
\hline Didymin & $146.3 \pm 0.2$ & $72.8 \pm \widehat{0} .2$ \\
\hline Naringin $6^{\prime \prime}$-malonate & $<\mathrm{LOQ}$ & $<\overline{L O Q}$ \\
\hline Naringin hydrate & $35.1 \pm 0.2$ & $51.7 \pm 0.2$ \\
\hline Dihydroisorhamnetin 7-rutinoside & $8.4 \pm 0.2$ & $10.1 \pm 0.06$ \\
\hline Isorhamnetin-3-O-rutinoside isomer a & $135.4 \pm 0.6$ & $116.6 \pm 0.3$ \\
\hline Isorhamnetin-3-O-rutinoside isomer b & $10.6 \pm 0.1$ & $8.0 \pm 0.0005$ \\
\hline Isorhamnetin-3-O-rutinoside isomer c & $54.6 \pm 0.1$ & $48.9 \pm 0.002$ \\
\hline Vitexin-O-pentoside isomer a & $72.2 \pm 0.5$ & $68.61 \pm 0.27$ \\
\hline Vitexin-O-pentoside isomer $\mathrm{b}$ & $111.5 \pm 0.01$ & $94.6 \pm 0.2$ \\
\hline Apigenin 7-O-neohesperidoside & $14.8 \pm 0.1$ & $9.2 \pm 0.5$ \\
\hline Apigenin-di-C-hexoside (Vicenin-2) isomer a & $570.7 \pm 0.9$ & $318.3 \pm 0.4$ \\
\hline Apigenin-di-C-hexoside (Vicenin-2) isomer b & $<$ LOQ & $<$ LOQ \\
\hline Apigenin-di-C-hexoside (Vicenin-2) isomer c & $7.7 \pm 0.2$ & $13.7 \pm 0.1$ \\
\hline Apigenin-di-C-hexoside (Vicenin-2) isomer $\mathrm{d}$ & $22.3 \pm 0.1$ & $16.3 \pm 0.1$ \\
\hline Apigenin-di-C-hexoside (Vicenin-2) isomer e & $<$ LOQ & $<$ LOQ \\
\hline Luteolin- $C$-hexoside- $C$-pentoside isomer a & $1.2 \pm 0.1$ & $0.2 \pm 0.01$ \\
\hline Luteolin- $C$-hexoside- $C$-pentoside isomer $b$ & $3.8 \pm 0.1$ & $2.3 \pm 0.02$ \\
\hline
\end{tabular}


Table 7. Cont

\begin{tabular}{|c|c|c|}
\hline Compounds & $\begin{array}{l}\text { Fresh By-Product } \\
(\mu g / g \text { d.w. })\end{array}$ & $\begin{array}{l}\text { Dry By-Product } \\
(\mu g / g \text { d.w. })\end{array}$ \\
\hline Kaempferol 3-[2" -glucosyl-6" ${ }^{\prime \prime}$-acetyl-galactoside] 7-glucoside isomer a & $24.6 \pm 0.3$ & $16.0 \pm 0.004$ \\
\hline Kaempferol 3-[2" -glucosyl-6" $6^{\prime \prime}$-acetyl-galactoside] 7-glucoside isomer b & $16.9 \pm 0.7$ & $12.3 \pm 0.04$ \\
\hline Kaempferol-dihexosyl acetate & $<\mathrm{LOQ}$ & $<\mathrm{LOQ}$ \\
\hline Kaempferol 3-O-(6"-O-acetyl) glucoside-7-O-rhamnoside & $<\mathrm{LOQ}$ & $<\mathrm{LOQ}$ \\
\hline Kaempferol 3-apiosyl-(1->4)-rhamnoside-7-rhamnoside & $<\mathrm{LOQ}$ & $<\mathrm{LOQ}$ \\
\hline kaempferol 3-O-[3", $6^{\prime \prime}$-di-O-(E)-cinnamoyl]- $\beta$-D-glucopyranoside & $0.7 \pm 0.06$ & $0.3 \pm 0.002$ \\
\hline Kaempferol 3-O-sinapoyl-caffeoyl-sophoroside 7-O-glucoside isomer a & $<\mathrm{LOQ}$ & $<\mathrm{LOQ}$ \\
\hline Kaempferol 3-O-sinapoyl-caffeoyl-sophoroside 7-O-glucoside isomer b & $<\mathrm{LOQ}$ & $<\mathrm{LOQ}$ \\
\hline Kaempferol 3-O-feruloyl-caffeoyl-sophoroside 7-O-glucoside isomer c & $<\mathrm{LOQ}$ & $<\mathrm{LOQ}$ \\
\hline Quercetin-O-dihexoside & $<\mathrm{LOQ}$ & $<\mathrm{LOQ}$ \\
\hline Quercetin-3-O-rutinoside-7-O-Glucoside & $<\mathrm{LOQ}$ & $<\mathrm{LOQ}$ \\
\hline Demethylnobiletin & n.d. & $<\mathrm{LOQ}$ \\
\hline $3^{\prime}, 4^{\prime}$-Didemethylnobiletin & $<\mathrm{LOQ}$ & $<\mathrm{LOQ}$ \\
\hline Naringenin & $11.5 \pm 0.02$ & $9.4 \pm 0.009$ \\
\hline Pectolinarigenin & $<\mathrm{LOQ}$ & $<\mathrm{LOQ}$ \\
\hline Isosakuranetin & n.d. & $<\mathrm{LOQ}$ \\
\hline Unknown flavonoid & $60.3 \pm 0.1$ & $125.8 \pm 0.5$ \\
\hline
\end{tabular}

n.d.: non-detected; LOQ: Limit of quantification.

Phenolic acids represented the $61 \%$ of the total phenolic compounds found in the dry orange by-product being $48 \%$ of those found in the fresh by-product. The most concentrated phenolic acid in fresh and dry by-products were 2-(E)-O-feruloyl-D-galactaric acid isomers b and c, accounting for 18.6 and $19.5 \%$, respectively. 2-(E)-O-feruloyl-D-galactaric acid isomers were approximately, $40-50 \%$ of the phenolic acids present in orange by-products. After those compounds, norbergenin accounted for $12 \%$ of the phenolic acids in both byproducts. The major caffeic acid derivatives were caffeoylglycolic acid methyl ester isomers $a$ and $b$, accounting for the $18 \%$ and $16 \%$ in the fresh and dry by-products, respectively.

The total amount of flavonoids found in the dry and fresh samples represented the $39 \%$ and $52 \%$ of the total phenolic compounds, respectively. The two most concentrated flavonoids, both, in the fresh and dry by-products were hesperidin and narirutin. However, in the fresh sample, they account for $45 \%$ of the present flavonoids, whereas in the dry one they were the $35 \%$. A study which optimized the extraction of these two compounds from the orange peel by subcritical water extraction, obtained an extract in which both compounds were approximately $21 \%$ of the total amount of flavonoids, a smaller value than the obtained with this optimized technique [35]. Other studies agree with us about the major compound found, hesperidin. Using an ultrasonic bath, Khan et al. found hesperidin as major compound getting an amount of $146.73 \mu \mathrm{g} / \mathrm{g}$ d.w. [29]. Barrales et al. obtained an extract mainly composed by hesperidin $(160 \mu \mathrm{g} / \mathrm{g}$ d.w. $)$ and narirutin $(120 \mu \mathrm{g} / \mathrm{g} \mathrm{d.w.})$ [3] with ultrasound bath technology. Despite not being the principal aim of this study, hesperidin and narirutin content was higher than the described in previous studies that used ultrasound technology applied to orange by-products.

The fourth most abundant flavonoid was apigenin-di-C-hexoside (Vicenin-2) isomer a, being around $17.5 \%$ of the flavonoids in both samples. For the dry by-product the fifth and sixth most abundant compounds were an unknown flavonoid $(6.8 \%)$ and vitexinO-pentoside isomer $\mathrm{b}(5.1 \%)$, whereas for the fresh one they are didymin $(4.5 \%)$, and prunin $(3.8 \%)$.

Taking into account the antioxidant activity, the fresh orange by-product has been found to have a higher activity than the dry one, with values of 66.39 and $74.32 \mathrm{mg}$ TE/g d.w. for the DPPH and ABTS assays, respectively (Figure 5).

This can be explained because the fresh by-product has a higher amount of total phenolic compounds than the dry one. The loss is around 25\% of the total phenolic 
compounds which means the loss of $43 \%$ of the flavonoids, $6 \%$ of the phenolic acids and consequently the loss of $50-60 \%$ of the antioxidant activity.

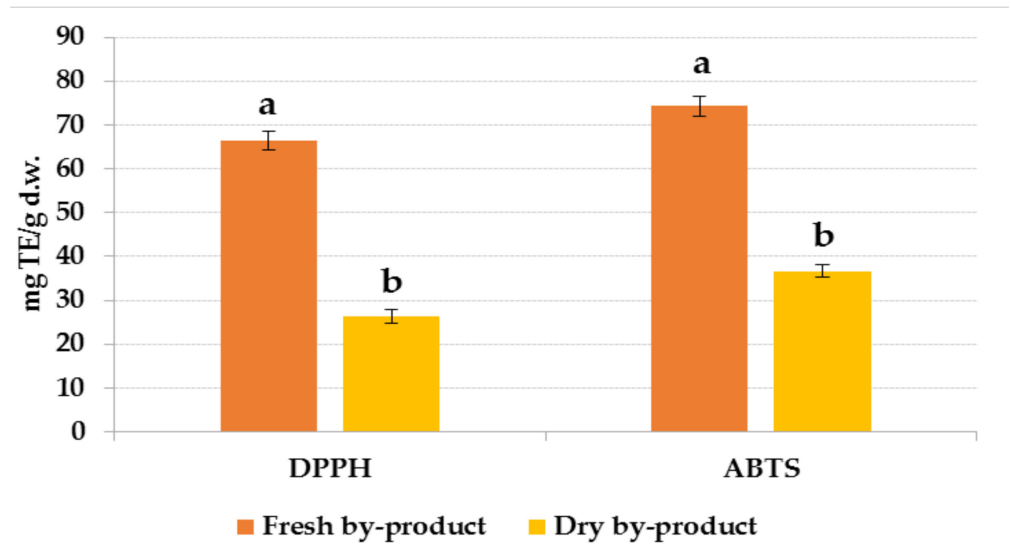

Figure 5. Comparison of antioxidant activities by two methods (DPPH and ABTS) in fresh and dry orange by-products extracts expressed in mg TE/g d.w. Different letters reported statistical significant differences.

\section{Conclusions}

An extraction based on ultrasound-assisted extraction by sonotrode has been optimized for obtaining the higher amounts of phenolic compounds with high antioxidant activity from the orange by-products. The results of this study have shown that applying the sonotrode extraction is possible to increase $60 \%$ more the phenolic recovery compared to a conventional extraction procedure as maceration. Moreover, sonotrode extraction has demonstrated to be faster than the conventional ones. In addition, the extracts have been exhaustively characterized identifying a total of 74 compounds in orange peels being 32 of them tentatively identified in orange by-products for the first time. The distribution of the phenolic compounds is mainly phenolic acids and flavonoids, especially flavonoid glycosides. The effect of drying was also evaluated and, as expected, it caused the loss of $25 \%$ of phenolic compounds; perhaps, an optimization of the drying conditions should be carried out in order to limit the phenolic degradation. Finally, the sonotrode ultrasound technology could be scaled-up to pilot and industrial scale in order to obtain orange by-products extracts that could be used as functional ingredients for food, feed and cosmeceutical scopes. However, to corroborate the potential (bio)-activity of the extracts, further in vitro and in vivo assays should be done.

Author Contributions: Conceptualization, V.V. and E.J.G.-H.; investigation, M.d.C.R.-D.; data curation, M.d.C.R.-D., A.M.G.-C. and C.R.-P.; writing—original draft preparation, M.d.C.R.-D.; writingreview and editing, V.V., E.J.G.-H., B.G.-V., A.M.G.-C. and C.R.-P.; supervision, V.V. and E.J.G.-H.; funding acquisition, V.V. All authors have read and agreed to the published version of the manuscript.

Funding: This study is part of the SHEALTHY project that has received funding from European Union's Horizon 2020 research and innovation program under grant agreement No 817936. Celia Rodríguez-Pérez thanks the University of Granada for the PPJIA2019-04 project.

Institutional Review Board Statement: Not applicable.

Informed Consent Statement: Not applicable.

Data Availability Statement: Not applicable.

Acknowledgments: Vito Verardo thanks the Spanish Ministry of Economy and Competitiveness (MINECO) for "Ramon y Cajal" contract (RYC-2015-18795).

Conflicts of Interest: The authors declare no conflict of interest. 


\section{References}

1. Romero-Lopez, M.R.; Osorio-Diaz, P.; Bello-Perez, L.A.; Tovar, J.; Bernardino-Nicanor, A. Fiber concentrate from orange (Citrus sinensis L.) bagase: Characterization and application as bakery product ingredient. Int. J. Mol. Sci. 2011, 12, 2174-2186. [CrossRef] [PubMed]

2. Razola-Díaz, M.d.C.; Guerra-Hernández, E.J.; García-Villanova, B.; Verardo, V. Recent developments in extraction and encapsulation techniques of orange essential oil. Food Chem. 2021, 354, 129575. [CrossRef] [PubMed]

3. Barrales, F.M.; Silveira, P.; Barbosa, P.; Barbosa, P.D.P.M.; Ruviaro, A.R.; Paulino, B.N.; Pastore, G.M.; Macedo, G.A.; Martinez, J. Recovery of phenolic compounds from citrus by-products using pressurized liquids-An application to orange peel. Food Bioprod. Process. 2018, 112, 9-21. [CrossRef]

4. Mamma, D.; Christakopoulos, P. Biotransformation of Citrus By-Products into Value Added Products. Waste Biomass Valorization 2014, 5, 529-549. [CrossRef]

5. Okino-Delgado, C.H.; Fleuri, L.F. Obtaining lipases from byproducts of orange juice processing. Food Chem. 2014, 163, 103-107. [CrossRef]

6. El Kantar, S.; Boussetta, N.; Rajha, H.N.; Maroun, R.G.; Louka, N.; Vorobiev, E. High voltage electrical discharges combined with enzymatic hydrolysis for extraction of polyphenols and fermentable sugars from orange peels. Food Res. Int. 2018, 107, 755-762 [CrossRef] [PubMed]

7. De Castro, L.A.; Lizi, J.M.; das Chagas, E.G.L.; de Carvalho, R.A.; Vanin, F.M. From orange juice by-product in the food industry to a functional ingredient: Application in the circular economy. Foods 2020, 9, 593. [CrossRef]

8. Sicari, V.; Pellicanò, T.M.; Laganà, V.; Poiana, M. Use of orange by-products (dry peel) as an alternative gelling agent for marmalade production: Evaluation of antioxidant activity and inhibition of HMF formation during different storage temperature. J. Food Process. Preserv. 2018, 42, e13429. [CrossRef]

9. De Moraes Crizel, T.; Jablonski, A.; de Oliveira Rios, A.; Rech, R.; Flôres, S.H. Dietary fiber from orange byproducts as a potential fat replacer. LWT Food Sci. Technol. 2013, 53, 9-14. [CrossRef]

10. Wang, S.; He, N.; Xing, H.; Sun, Y.; Ding, J.; Liu, L. Function of hesperidin alleviating inflammation and oxidative stress responses in COPD mice might be related to SIRT1/PGC-1 $\alpha$ /NF- $\mathrm{kB}$ signaling axis. J. Recept. Signal Transduct. 2020, 40, 388-394. [CrossRef]

11. Liu, L.; Shan, S.; Zhang, K.; Ning, Z.-Q.; Lu, X.-P.; Cheng, Y.-Y. Naringenin and hesperetin, two flavonoids derived from Citrus aurantium up-regulate transcription of adiponectin. Phyther. Res. 2008, 22, 1400-1403. [CrossRef]

12. Choi, E.J.; Kim, G.H. Anti-/pro-apoptotic effects of hesperetin against 7,12-dimetylbenz(a) anthracene-induced alteration in animals. Oncol. Rep. 2011, 25, 545-550. [CrossRef] [PubMed]

13. Guardia, T.; Rotelli, A.E.; Juarez, A.O.; Pelzer, L.E. Anti-inflammatory properties of plant flavonoids. Effects of rutin, quercetin and hesperidin on adjuvant arthritis in rat. Farmaco 2001, 56, 683-687. [CrossRef]

14. Mahmoud, A.M.; Ashour, M.B.; Abdel-Moneim, A.; Ahmed, O.M. Hesperidin and naringin attenuate hyperglycemia-mediated oxidative stress and proinflammatory cytokine production in high fat fed/streptozotocin-induced type 2 diabetic rats. J. Diabetes Complicat. 2012, 26, 483-490. [CrossRef]

15. Elavarasan, J.; Velusamy, P.; Ganesan, T.; Ramakrishnan, S.K.; Rajasekaran, D.; Periandavan, K. Hesperidin-mediated expression of Nrf2 and upregulation of antioxidant status in senescent rat heart. J. Pharm. Pharmacol. 2012, 64, 1472-1482. [CrossRef]

16. Deng, L.Z.; Mujumdar, A.S.; Yang, W.X.; Zhang, Q.; Zheng, Z.A.; Wu, M.; Xiao, H.W. Hot air impingement drying kinetics and quality attributes of orange peel. J. Food Process. Preserv. 2020, 44, e14294. [CrossRef]

17. Wang, L.; Weller, C.L. Recent advances in extraction of nutraceuticals from plants. Trends Food Sci. Technol. 2006, 17, 300-312. [CrossRef]

18. Garau, M.C.; Simal, S.; Rosselló, C.; Femenia, A. Effect of air-drying temperature on physico-chemical properties of dietary fibre and antioxidant capacity of orange (Citrus aurantium v. Canoneta) by-products. Food Chem. 2007, 104, 1014-1024. [CrossRef]

19. Abdurrahman Isa, A.; Samsuri, S.; Aini Amran, N. Integration of Maceration and Freeze Concentration for Recovery of Vitamin C from Orange Peel Waste. IOP Conf. Ser. Earth Environ. Sci. 2019, 268, 012101. [CrossRef]

20. Singleton, V.L.; Orthofer, R.; Lamuela-Raventós, R.M. Analysis of Total Phenols and other oxidation substrates and antioxidants by means of Folin-Ciocalteu Reagent. In Oxidants and Antioxidants Part A, Methods in Enzymology; Academic Press: Boston, MA, USA, 1999; Volume 299, pp. 152-178.

21. Verni, M.; Pontonio, E.; Krona, A.; Jacob, S.; Pinto, D.; Rinaldi, F.; Verardo, V.; Díaz-de-Cerio, E.; Coda, R.; Rizzello, C.G. Bioprocessing of Brewers' Spent Grain Enhances Its Antioxidant Activity: Characterization of Phenolic Compounds and Bioactive Peptides. Front. Microbiol. 2020, 11, 1831. [CrossRef] [PubMed]

22. Re, R.; Pellegrini, N.; Proteggente, A.; Pannala, A.; Yang, M.; Rice-Evans, C. Antioxidant activity applying an improved ABTS radical cation decolorization assay. Free Radic. Biol. Med. 1999, 26, 1231-1237. [CrossRef]

23. Brand-Williams, W.; Cuvelier, M.E.; Berset, C. Use of a free redical method to evaluate antioxidant activity. LWT Food Sci. Technol. 1995, 28, 25-30. [CrossRef]

24. Parejo, I.; Codina, C.; Petrakis, C.; Kefalas, P. Evaluation of scavenging activity assessed by Co(II)/EDTA-induced luminol chemiluminescence and DPPH·(2,2-diphenyl-1-picrylhydrazyl) free radical assay. J. Pharmacol. Toxicol. Methods 2000, 44, 507-512. [CrossRef] 
25. Victor, M.M.; David, J.M.; Cortez, M.V.M.; Leite, J.L.; da Silva, G.S.B. A High-Yield Process for Extraction of Hesperidin from Orange (Citrus sinensis L. osbeck) Peels Waste, and Its Transformation to Diosmetin, A Valuable and Bioactive Flavonoid. Waste Biomass Valorization 2021, 12, 313-320. [CrossRef]

26. Lagha-Benamrouche, S.; Madani, K. Phenolic contents and antioxidant activity of orange varieties (Citrus sinensis L. and Citrus aurantium L.) cultivated in Algeria: Peels and leaves. Ind. Crops Prod. 2013, 50, 723-730. [CrossRef]

27. Nayak, B.; Dahmoune, F.; Moussi, K.; Remini, H.; Dairi, S.; Aoun, O.; Khodir, M. Comparison of microwave, ultrasound and accelerated-assisted solvent extraction for recovery of polyphenols from Citrus sinensis peels. Food Chem. 2015, 187, 507-516. [CrossRef]

28. Montero-Calderon, A.; Cortes, C.; Zulueta, A.; Frigola, A.; Esteve, M.J. Green solvents and Ultrasound-Assisted Extraction of bioactive orange (Citrus sinensis) peel compounds. Sci. Rep. 2019, 9, 16120. [CrossRef]

29. Khan, M.K.; Abert-Vian, M.; Fabiano-Tixier, A.S.; Dangles, O.; Chemat, F. Ultrasound-assisted extraction of polyphenols (flavanone glycosides) from orange (Citrus sinensis L.) peel. Food Chem. 2010, 119, 851-858. [CrossRef]

30. Shahram, H.; Dinani, S.T.; Amouheydari, M. Effects of pectinase concentration, ultrasonic time, and pH of an ultrasonic-assisted enzymatic process on extraction of phenolic compounds from orange processing waste. J. Food Meas. Charact. 2019, 13, 487-498. [CrossRef]

31. Luengo, E.; Álvarez, I.; Raso, J. Improving the pressing extraction of polyphenols of orange peel by pulsed electric fields. Innov. Food Sci. Emerg. Technol. 2013, 17, 79-84. [CrossRef]

32. El Kantar, S.; Rajha, H.N.; Maroun, R.G.; Louka, N. Intensification of polyphenols extraction from orange peels using infrared as a novel and energy saving pretreatment. J. Food Sci. 2020, 85, 414-420. [CrossRef] [PubMed]

33. Hernández-Carranza, P.; Ávila-Sosa, R.; Guerrero-Beltrán, J.A.; Navarro-Cruz, A.R.; Corona-Jiménez, E.; Ochoa-Velasco, C.E. Optimization of Antioxidant Compounds Extraction from Fruit By-Products: Apple Pomace, Orange and Banana Peel. J. Food Process. Preserv. 2016, 40, 103-115. [CrossRef]

34. Park, J.H.; Lee, M.; Park, E. Antioxidant activity of orange flesh and peel extracted with various solvents. Prev. Nutr. Food Sci. 2014, 19, 291-298. [CrossRef]

35. Lachos-Perez, D.; Baseggio, A.M.; Mayanga-Torres, P.C.; Maróstica, M.R.; Rostagno, M.A.; Martínez, J.; Forster-Carneiro, T. Subcritical water extraction of flavanones from defatted orange peel. J. Supercrit. Fluids 2018, 138, 7-16. [CrossRef]

36. Saleem, M.; Hyoung, J.K.; Jin, C.; Yong, S.L. Antioxidant caffeic acid derivatives from leaves of Parthenocissus tricuspidata. Arch. Pharm. Res. 2004, 27, 300-304. [CrossRef] [PubMed]

37. Hahn, R.; Nahrstedt, A. Hydroxycinnamic acid derivatives, caffeoylmalic and new caffeoylaldonic acid esters, from Chelidonium majus. Planta Med. 1993, 59, 71-75. [CrossRef]

38. Tang, J.; Dunshea, F.R.; Suleria, H.A.R. LC-ESI-QTOF/MS characterization of phenolic compounds from medicinal plants (Hops and Juniper Berries) and their antioxidant activity. Foods 2020, 9, 7. [CrossRef]

39. Jabri Karoui, I.; Marzouk, B. Characterization of bioactive compounds in Tunisian bitter orange (Citrus aurantium L.) peel and juice and determination of their antioxidant activities. Biomed Res. Int. 2013, 2013, 345415. [CrossRef]

40. Gorinstein, S.; Martín-Belloso, O.; Park, Y.S.; Haruenkit, R.; Lojek, A.; Íž, M.; Caspi, A.; Libman, I.; Trakhtenberg, S. Comparison of some biochemical characteristics of different citrus fruits. Food Chem. 2001, 74, 309-315. [CrossRef]

41. Risch, B.; Herrmann, K.; Wray, V.; Grotjahn, L. 2'-(E)-O-p-coumaroylgalactaric acid and 2'-(E)-O-feruloylgalactaric acid in citrus. Phytochemistry 1987, 26, 509-510. [CrossRef]

42. Lu, Q.; Lv, S.; Peng, Y.; Zhu, C.; Pan, S. Characterization of phenolics and antioxidant abilities of red navel orange "cara cara" harvested from five regions of china. Int. J. Food Prop. 2018, 21, 1107-1116. [CrossRef]

43. Anagnostopoulou, M.A.; Kefalas, P.; Kokkalou, E.; Assimopoulou, A.N.; Papageorgiou, V.P. Analysis of antioxidant compounds in sweet orange peel by HPLC-diode array detection-electrospray ionization mass spectrometry. Biomed. Chromatogr. 2005, 19, 138-148. [CrossRef]

44. Bocco, A.; Cuvelier, M.E.; Richard, H.; Berset, C. Antioxidant Activity and Phenolic Composition of Citrus Peel and Seed Extracts. J. Agric. Food Chem. 1998, 46, 2123-2129. [CrossRef]

45. Masike, K.; Mhlongo, M.I.; Mudau, S.P.; Nobela, O.; Ncube, E.N.; Tugizimana, F.; George, M.J.; Madala, N.E. Highlighting mass spectrometric fragmentation differences and similarities between hydroxycinnamoyl-quinic acids and hydroxycinnamoyl-isocitric acids. Chem. Cent. J. 2017, 11, 29. [CrossRef] [PubMed]

46. Kvasnička, F.; Voldřich, M.; Pyš, P.; Vinš, I. Deterimination of isocitric acid in citrus juice-A comparison of HPLC, enzyme set and capillary isotachophoresis methods. J. Food Compos. Anal. 2002, 15, 685-691. [CrossRef]

47. Ehling, S.; Cole, S. Analysis of organic acids in fruit juices by liquid chromatography-mass spectrometry: An enhanced tool for authenticity testing. J. Agric. Food Chem. 2011, 59, 2229-2234. [CrossRef] [PubMed]

48. Nazir, N.; Koul, S.; Qurishi, M.A.; Taneja, S.C.; Ahmad, S.F.; Bani, S.; Qazi, G.N. Immunomodulatory effect of bergenin and norbergenin against adjuvant-induced arthritis-A flow cytometric study. J. Ethnopharmacol. 2007, 112, 401-405. [CrossRef]

49. Ma, Y.Q.; Ye, X.Q.; Fang, Z.X.; Chen, J.C.; Xu, G.H.; Liu, D.H. Phenolic compounds and antioxidant activity of extracts from ultrasonic treatment of satsuma mandarin (Citrus unshiu Marc.) peels. J. Agric. Food Chem. 2008, 56, 5682-5690. [CrossRef]

50. Anagnostopoulou, M.A.; Kefalas, P.; Papageorgiou, V.P.; Assimopoulou, A.N.; Boskou, D. Radical scavenging activity of various extracts and fractions of sweet orange peel (Citrus sinensis). Food Chem. 2006, 94, 19-25. [CrossRef] 
51. Allaf, T.; Tomao, V.; Besombes, C.; Chemat, F. Thermal and mechanical intensification of essential oil extraction from orange peel via instant autovaporization. Chem. Eng. Process. Process Intensif. 2013, 72, 24-30. [CrossRef]

52. Khan, M.K.; Zill-E-Huma; Dangles, O. A comprehensive review on flavanones, the major citrus polyphenols. J. Food Compos. Anal. 2014, 33, 85-104. [CrossRef]

53. Vanamala, J.; Reddivari, L.; Yoo, K.S.; Pike, L.M.; Patil, B.S. Variation in the content of bioactive flavonoids in different brands of orange and grapefruit juices. J. Food Compos. Anal. 2006, 19, 157-166. [CrossRef]

54. Chen, X.M.; Tait, A.R.; Kitts, D.D. Flavonoid composition of orange peel and its association with antioxidant and anti-inflammatory activities. Food Chem. 2017, 218, 15-21. [CrossRef] [PubMed]

55. Iglesias-Carres, L.; Mas-Capdevila, A.; Bravo, F.I.; Aragonès, G.; Muguerza, B.; Arola-Arnal, A. Optimization of a polyphenol extraction method for sweet orange pulp (Citrus sinensis L.) to identify phenolic compounds consumed from sweet oranges. PLoS ONE 2019, 14, e0211267. [CrossRef]

56. Omoba, O.S.; Obafaye, R.O.; Salawu, S.O.; Boligon, A.A.; Athayde, M.L. HPLC-DAD phenolic characterization and antioxidant activities of ripe and unripe sweet orange peels. Antioxidants 2015, 4, 498-512. [CrossRef]

57. Berhow, M.A.; Vandercook, C.E. Biosynthesis of naringin and prunin in detached grapefruit. Phytochemistry 1989, 28, 1627-1630. [CrossRef]

58. Castillo, J.; Benavente, O.; del Rio, J.A. Hesperetin 7-O-Glucoside and Prunin in Citrus Species (C. aurantium and C. paradisi). A Study of Their Quantitative Distribution in Immature Fruits and as Immediate Precursors of Neohesperidin and Naringin in C. aurantium. J. Agric. Food Chem. 1993, 41, 1920-1924. [CrossRef]

59. Fayek, N.M.; Farag, M.A.; Abdel Monem, A.R.; Moussa, M.Y.; Abd-Elwahab, S.M.; El-Tanbouly, N.D. Comparative Metabolite Profiling of Four Citrus Peel Cultivars via Ultra-Performance Liquid Chromatography Coupled with Quadrupole-Time-of-FlightMass Spectrometry and Multivariate Data Analyses. J. Chromatogr. Sci. 2019, 57, 349-360. [CrossRef]

60. Gattuso, G.; Barreca, D.; Gargiulli, C.; Leuzzi, U.; Caristi, C. Flavonoid composition of citrus juices. Molecules 2007, 12, 1641-1673. [CrossRef] [PubMed]

61. Goh, J.X.H.; Tan, L.T.H.; Goh, J.K.; Chan, K.G.; Pusparajah, P.; Lee, L.H.; Goh, B.H. Nobiletin and derivatives: Functional compounds from citrus fruit peel for colon cancer chemoprevention. Cancers 2019, 11, 867. [CrossRef]

62. Nakazawa, Y.; Aoki, M.; Ishiwa, S.; Morishita, N.; Endo, S.; Nagai, N.; Yamamoto, N.; Funakoshi-Tago, M.; Tamura, H. Oral intake of $\alpha$-glucosyl-hesperidin ameliorates selenite-induced cataract formation. Mol. Med. Rep. 2020, 21, 1258-1266. [CrossRef] [PubMed]

63. Sugasawa, N.; Katagi, A.; Kurobe, H.; Nakayama, T.; Nishio, C.; Takumi, H.; Higashiguchi, F.; Aihara, K.; Shimabukuro, M.; Sata, M.; et al. Inhibition of Atherosclerotic Plaque Development by Oral Administration of $\alpha$-Glucosyl Hesperidin and Water-Dispersible Hesperetin in Apolipoprotein E Knockout Mice. J. Am. Coll. Nutr. 2019, 38, 15-22. [CrossRef] [PubMed]

64. Lipson, S.M.; Ozen, F.S.; Louis, S.; Karthikeyan, L. Comparison of $\alpha$-glucosyl hesperidin of citrus fruits and epigallocatechin gallate of green tea on the Loss of Rotavirus Infectivity in Cell Culture. Front. Microbiol. 2015, 6, 359. [CrossRef] [PubMed]

65. Uchiyama, H.; Tozuka, Y.; Imono, M.; Takeuchi, H. Improvement of dissolution and absorption properties of poorly water-soluble drug by preparing spray-dried powders with $\alpha$-glucosyl hesperidin. Int. J. Pharm. 2010, 392, 101-106. [CrossRef]

66. Tozuka, Y.; Imono, M.; Uchiyama, H.; Takeuchi, H. A novel application of $\alpha$-glucosyl hesperidin for nanoparticle formation of active pharmaceutical ingredients by dry grinding. Eur. J. Pharm. Biopharm. 2011, 79, 559-565. [CrossRef]

67. Abad-García, B.; Garmón-Lobato, S.; Berrueta, L.A.; Gallo, B.; Vicente, F. On line characterization of 58 phenolic compounds in Citrus fruit juices from Spanish cultivars by high-performance liquid chromatography with photodiode-array detection coupled to electrospray ionization triple quadrupole mass spectrometry. Talanta 2012, 99, 213-224. [CrossRef]

68. Brito, A.; Ramirez, J.E.; Areche, C.; Sepúlveda, B.; Simirgiotis, M.J. HPLC-UV-MS profiles of phenolic compounds and antioxidant activity of fruits from three citrus species consumed in Northern Chile. Molecules 2014, 19, 17400-17421. [CrossRef] [PubMed]

69. Roriz, C.L.; Barros, L.; Carvalho, A.M.; Santos-Buelga, C.; Ferreira, I.C.F.R. Pterospartum tridentatum, Gomphrena globosa and Cymbopogon citratus: A phytochemical study focused on antioxidant compounds. Food Res. Int. 2014, 62, 684-693. [CrossRef]

70. FooDB-Kaempferol 3-[2" -glucosyl-6"-Acetyl-Galactoside] 7-Glucoside. Available online: https:/ / foodb.ca/compounds / FDB016 214 (accessed on 15 January 2021).

71. Calderón-Montaño, J.M.; Burgos-Morón, E.; Pérez-Guerrero, C.; López-Lázaro, M. A Review on the Dietary Flavonoid Kaempferol I BenthamScience. Mini Rev. Med. Chem. 2011, 11, 298-344. [CrossRef]

72. Ferreres, F.; Sousa, C.; Vrchovská, V.; Valentão, P.; Pereira, J.A.; Seabra, R.M.; Andrade, P.B. Chemical composition and antioxidant activity of tronchuda cabbage internal leaves. Eur. Food Res. Technol. 2006, 222, 88-98. [CrossRef]

73. Zanzer, Y.C.; Plaza, M.; Dougkas, A.; Turner, C.; Östman, E. Black pepper-based beverage induced appetite-suppressing effects without altering postprandial glycaemia, gut and thyroid hormones or gastrointestinal well-being: A randomized crossover study in healthy subjects. Food Funct. 2018, 9, 2774-2786. [CrossRef] [PubMed]

74. Berhow, M.A.; Bennett, R.D.; Kanes, K.; Poling, S.M.; Vandercook, C.E. A malonic acid ester derivative of naringin in grapefruit. Phytochemistry 1991, 30, 4198-4200. [CrossRef]

75. Kanes, K.; Tisserat, B.; Berhow, M.; Vandercook, C. Phenolic composition of various tissues of rutaceae species. Phytochemistry 1993, 32, 967-974. [CrossRef]

76. Cheriet, T.; Ben-Bachir, B.; Thamri, O.; Seghiri, R.; Mancini, I. Isolation and biological properties of the natural flavonoids pectolinarin and pectolinarigenin-A review. Antibiotics 2020, 9, 417. [CrossRef] [PubMed] 
77. Yang, Y.; Zhao, X.J.; Pan, Y.; Zhou, Z. Identification of the chemical compositions of Ponkan peel by ultra performance liquid chromatography coupled with quadrupole time-of-flight mass spectrometry. Anal. Methods 2016, 8, 893-903. [CrossRef]

78. Gualdani, R.; Cavalluzzi, M.M.; Lentini, G.; Habtemariam, S. The chemistry and pharmacology of citrus limonoids. Molecules 2016, 21, 1530. [CrossRef] [PubMed]

79. Shi, Y.S.; Zhang, Y.; Li, H.T.; Wu, C.H.; El-Seedi, H.R.; Ye, W.K.; Wang, Z.W.; Li, C.B.; Zhang, X.F.; Kai, G.Y. Limonoids from Citrus: Chemistry, anti-tumor potential, and other bioactivities. J. Funct. Foods 2020, 75, 104213. [CrossRef]

80. Umehara, K.; Hattori, I.; Miyase, T.; Ueno, A.; Hara, S.; Kageyama, C. Studies on the Constituents of Leaves of Citrus unshiu Marcov. Chem. Pharm. Bull. 1988, 36, 5004-5008. [CrossRef]

81. Liew, S.S.; Ho, W.Y.; Yeap, S.K.; Bin Sharifudin, S.A. Phytochemical composition and in vitro antioxidant activities of Citrus sinensis peel extracts. Peer] 2018, 2018, e5331. [CrossRef] 